\title{
SAVING AND DEMOGRAPHIC CHANGE: THE GLOBAL DIMENSION
}

\author{
Barry Bosworth and Gabriel Chodorow-Reich*
}

CRR WP 2007-2

Released: February 2007

Draft Submitted: December 2006

\author{
Center for Retirement Research at Boston College \\ Hovey House \\ 140 Commonwealth Avenue \\ Chestnut Hill, MA 02467 \\ Tel: 617-552-1762 Fax: 617-552-0191 \\ http://www.bc.edu/crr
}

* Barry Bosworth is a senior fellow at The Brookings Institution. Gabriel Chodorow-Reich is a senior research assistant at The Brookings Institution. The research reported herein was performed pursuant to a grant from the U.S. Social Security Administration (SSA) funded as part of the Retirement Research Consortium. The findings and conclusions are solely those of the authors and do not represent the views of SSA, any agency of the Federal Government, The Brookings Institution, or Boston College.

(C) 2007, by Barry Bosworth and Gabriel Chodorow-Reich. All rights reserved. Short sections of text, not to exceed two paragraphs, may be quoted without explicit permission provided that full credit, including (C) notice, is given to the source. 


\title{
About the Center for Retirement Research
}

The Center for Retirement Research at Boston College, part of a consortium that includes parallel centers at the University of Michigan and the National Bureau of Economic Research, was established in 1998 through a grant from the Social Security Administration. The Center's mission is to produce first-class research and forge a strong link between the academic community and decision makers in the public and private sectors around an issue of critical importance to the nation's future. To achieve this mission, the Center sponsors a wide variety of research projects, transmits new findings to a broad audience, trains new scholars, and broadens access to valuable data sources.

\author{
Center for Retirement Research at Boston College \\ Hovey House \\ 140 Commonwealth Avenue \\ Chestnut Hill, MA 02467 \\ phone: 617-552-1762 fax: 617-552-0191 \\ e-mail: crr@bc.edu \\ www.bc.edu/crr
}

\author{
Affiliated Institutions: \\ American Enterprise Institute \\ The Brookings Institution \\ Center for Strategic and International Studies \\ Massachusetts Institute of Technology \\ Syracuse University \\ Urban Institute
}




\begin{abstract}
This paper uses a panel data set of 85 countries covering 1960-2005 to investigate the macroeconomic linkages between national rates of saving and investment and population aging. The issue takes on added significance because of the recent suggestion that the decline in global interest rates has been driven by demographic changes in the industrial economies. We do find a significant correlation between the age composition of the population and nations' rates of saving and investment, but the effects vary substantially by region. They are very strong for the non-industrial economies of Asia, but weak in the high-income countries. We also find evidence of demographic effects on both the public and private components of national saving. Furthermore, we conclude that the demographic effects on saving will be less disruptive than sometimes believed because of offsetting declines in investment. However, the effects on saving are stronger than those for investment, implying that most aging economies will ultimately be pushed in the direction of current account deficits.

In contrast to some of the recent discussion, we find that demographic change is already exerting a downward pressure on saving in the high-income economies and that the current evidence of a global saving glut is related more to the weakness of investment - particularly in Asia - and the high short-run saving of the oil-producing countries. We conclude with a discussion of why the effects appear to be so strong in Asia.
\end{abstract}




\section{Introduction}

A decade ago, research on the impact of population aging on public and privatesector saving generated widespread concern about a growing scarcity of saving in the global economy, with its attendant pressures for rising real interest rates. ${ }^{1}$ Institutions such as the World Bank and the Organization for Economic Cooperation and Development (OECD) issued reports focused on what they perceived to be a looming crisis. Today, the attention of government policymakers has turned to the notion of a glut of global saving (Bernanke, 2005). Such a shift of emphasis seems particularly surprising from a U.S. perspective where the public discussion has focused on an ongoing decline of private saving and the re-emergence of large budget deficits. Certainly, the United States is not plagued by an oversupply of saving. The absence of saving in the United States, in conjunction with strong domestic investment opportunities, has created a current account deficit of unprecedented size - $\$ 800$ billion in 2005, and still growing. The United States has emerged as the world's largest debtor nation by a wide margin.

However, while one can be astounded by the size of the U.S. deficit, the ease with which it has been financed at the global level is equally surprising. Thus, there are two perspectives on the global saving imbalance: Why is there a large saving shortfall in the United States, and why is there such a large excess in the rest of the world? Furthermore, given that this has all occurred against the backdrop of low real interest rates around the globe, it can be asserted, as Bernanke did, that the greater puzzle is the excess saving in the rest of the world. Bernanke went on to attribute the saving surplus to demographic change, or more accurately the anticipation of future population aging and its attendant retirement costs, in the other industrial countries. In this view, high saving today results from the early phase of a demographic change that will impose a cycle of surplus followed by a substantial decline in saving at the global level.

This paper examines recent changes in the balance of saving and investment from a global perspective and examines the link between the changes in the balance across major regions and demographic changes in the age structure of the population. While Bernanke and others have emphasized the role of demographic change in first promoting

\footnotetext{
${ }^{1}$ See for example, OECD (1996), McKinsey Global Institute (1994), and Qureshi (1995).
} 
and then depressing rates of national saving in industrial countries, we show that the more pervasive changes have been in declining rates of investment in both industrial and developing countries. We have constructed a panel data set covering 85 countries over the period of 1960 to 2005 to examine the influence of demographic change on rates of saving and investment. We improve upon similar exercises that have been previously reported in the literature by expanding our data set to distinguish between public and private rates of saving. Thus we can analyze the impact of demographic changes on public budget balances, private saving, investment, and their net impact on the external balance. We also allow demographics to have a non-uniform impact in different regions.

Our primary conclusion is that we can identify significant demographic effects on national saving and government budget balances at the national level. However, the demographically-induced fall in saving within the industrial economies will be less disruptive than often assumed because of a similar offsetting decline in investment requirements. Second, the rapid development of a global capital market provides an important means of accommodating the change. Japan is an example of a country that has built up a very large net foreign investment position that can be used to finance future consumption. The United States has followed a different path, though its residents still have large wealth holdings that can be sold off in future years to finance continued consumption. Third, we find that the importance of demographic effects varies across regions. The impact in industrial countries appears rather weak, while Asia exhibits extremely large effects. Finally, to date, the influence of demographic change on both saving and investment has been very modest. Thus, its effects have been dominated by other developments in the global economy. In particular, it is not a significant factor behind the recent emergence of global saving-investment imbalances.

The following section provides an overview, at the level of major regions of the world, of recent trends in saving and investment that addresses some of the concerns raised by Bernanke. Section two introduces the role of demographic influences on both saving and investment and the methodology that we use to evaluate empirically the linkages between demographic change and national rates of saving and investment. We also provide a brief summary of the data set and the methods used to construct it. Our basic empirical results are reported in section three, and section four uses the empirical 
results to evaluate the importance of demographic change as an influence on current and future rates of saving and investment across major regions of the world. We conclude with a discussion of possible reasons for the strong demographic effect in Asia and a review of our major findings.

\section{Global Patterns of Saving and Investment}

At the global level, national patterns of saving and investment are linked through a simple accounting identity in which the difference between national saving and investment is equal to the external balance with the rest of the world, the current account:

(1) $C A=S-I$.

Furthermore, absent errors and omissions, the sum of the current accounts across all economies should equal zero. Thus, the deficits of some countries will be offset by surpluses of others. Prior to the 1970s, current account imbalances were strictly limited, as most national financial markets operated as closed systems. With the emergence of large-scale cross-border capital flows, countries have become capable of financing increasingly large imbalances on a sustained basis.

The dichotomy in the world economy between the external position of the United States and everyone else is highlighted in Table 1, which shows the current account balances for major regions of the world economy over the period of 1980 to 2005, providing a simple summary of the magnitude and distribution of the saving-investment imbalances. The United States clearly stands out for the size of its recent deficit, which is matched by surpluses in all other regions of the globe. At the same time, Europe's surplus has declined since the mid-1990s, and Japan's surplus has remained basically unchanged for nearly a quarter of a century. Similarly, little has changed in Latin America. The offsets to the increased U.S. deficit are the appearance of large surpluses in the emerging economies of Asia and the oil-producing economies of the Middle East. ${ }^{2}$ Given the rise of oil prices, the surge of saving within the oil-producing regions is not a

\footnotetext{
${ }^{2}$ Emerging Asia is a broad definition that includes the Newly Industrialized Economies (Hong Kong, Singapore, South Korea and Taiwan) as well as developing economies such as China and India. Complete definitions are provided in appendix A.
} 
surprise, but the sudden emergence of a large excess of saving over investment in Asia is less expected.

We can get a clearer picture of the evolving balances by focusing separately on the changes in rates of national saving and investment. The U.S. balance, shown in Figure 1, is dominated by an ongoing decline in the national saving rate that began in the early 1980s. Some of the recent drop can be traced to the recurrence of sustained negative saving in the public sector, but the household saving rate has also continued to fall, and on a net basis (excluding depreciation) it turned negative in 2005. Only corporate saving has held up in recent years, as profits soared after the 2001 recession. The large capital gains over the past two decades in equity markets and housing are undoubtedly part of the explanation for the reduced saving; but the correlation has not been very close - the saving decline preceded the boom in equity markets and saving has shown no signs of recovery after the 2001 stock market crash.

On the other side of the accounts, the United States continues to offer very good investment opportunities - superior to those of most other industrial countries - and the investment rate shows no secular pattern of decline comparable to that for saving. The combination of good investment opportunities and very little domestic saving with which to finance them has translated into an ever-growing reliance on the net inflow of resources from abroad. While the degree of reliance on foreign financing is unprecedented, it has been achieved with relatively few strains because foreigners also perceive the United States as offering very attractive investment opportunities. The primary cost is that the strong demand for dollar-denominated assets has kept the value of the dollar at a high level and greatly weakened the ability of U.S. firms to compete in global markets.

Bernanke argued that the low U.S. saving has been offset by an increase in global saving, including that of other industrial countries, and he emphasized demographic changes as a primary source of the increase. ${ }^{3}$ However, as shown in Figure 2, rates of both saving and investment have steadily fallen in the industrial countries, excluding the United States. In fact, the greatest contrast with the experience of the United States is

\footnotetext{
${ }^{3}$ The argument that the demographic factors are currently creating a substantial surplus of saving over investment has been offered by Brooks (2002) and MGI (1994).
} 
actually on the investment side. Rates of investment have fallen in both Japan and Europe, compared to the stability of the U.S. rate. This is undoubtedly due to their weak growth in recent decades. With parallel declines in their rates of saving and investment, Europe and Japan have experienced very little change in their net external balances.

Some of the decline in saving within the other industrial countries can be attributed to deterioration in the public sector balance that is even more pronounced than in the United States. Many of these countries formerly used strong public saving to supplement the private sector and support efforts to catch up to U.S. living standards. When they encountered economic problems in the 1980s (Europe) and 1990s (Japan), the surpluses disappeared. The result is that the rates of national saving and investment in other industrial countries are gradually declining toward those of the United States.

As the figures make clear, the United States has long been a nation of relatively low saving. In the past, however, the low saving was not particularly damaging to economic growth. Americans saved less, but invested the capital very efficiently. In part, this can be traced to highly developed capital markets and a minimum of government interference in the allocation of saving.

The most striking increase in the S-I balance is in emerging Asia. As shown in Figure 3, these are countries that have had high and rising rates of saving. ${ }^{4}$ It also appears that those high saving rates were concentrated in the private sector, since the governments generally avoided large budget surpluses or deficits. Several explanations have been put forth for this pattern of saving behavior. The sharp decline in birth rates has lowered the child dependency rate and encouraged adults to save for retirement since they can no longer simply rely on their children. Many of these countries have underdeveloped public retirement systems. Second, high growth creates a virtuous circle in which rapid income growth makes it easy to save at the same time that one's standard of living is improving, and the high saving feeds back through capital accumulation to promote further growth. This explanation received additional support when saving rates

\footnotetext{
${ }^{4}$ Our regional averages are constructed using commercial exchange rates to convert all of the data into a common currency.
} 
actually fell for a time after the Asian financial crisis, when growth slowed. ${ }^{5}$ Third, it is argued that some Asian countries have traditions of strong intergenerational linkages that may serve to promote dynastic saving and a longer-term perspective on wealth accumulation.

More importantly, the shift in the S-I balance within Asia can be traced primarily to changes on the investment side. The 1997 financial crisis had its greatest impact on investment spending, which fell precipitously; and, although these economies have recovered to a large extent, the rate of investment has not been restored to pre-crisis levels, even after the passage of nearly 10 years.

Finally, as measured by the decline in global interest rates (Figure 4), there is evidence of a pattern of a growing surplus of saving over investment. There has also been a substantial convergence of nations' real interest rates as national capital markets became more open. However, the longer-term decline in real interest rates, extending back to the early 1990s, is not reflective of a sudden emergence of a saving glut.

Overall, the surprise at the global level is that the story appears to be one of weak investment, rather than the rise in saving hypothesized by Bernanke. Also, this initial presentation does not seem supportive of a view of demographic change as a major factor in the recent developments, given the general declining pattern within the industrial countries, which should be preparing for large retirement cost increases in the near future. We will explore this aspect in a more systematic fashion in the following sections.

\section{Modeling Demographic Change}

Most of the world's societies are in the midst of substantial demographic transitions induced by sharply lower rates of fertility and mortality. The result is a sharply declining proportion of children in the population and a rising share of the elderly. However, there is a great diversity across countries and regions, as illustrated in Table 2. Within the high-income economies, the decline in birth rates began more than half a century ago, and the transition to a lower child dependency rate (the population below age 15 divided by the population aged 15 to 64), is largely complete. With a lag,

\footnotetext{
${ }^{5}$ The emphasis on a positive correlation with income change, however, is contrary to the perspective of the life-cycle model where expectations of strong future income growth should reduce current saving (Tobin, 1967).
} 
however, the lower birth rate also slows growth of the working-age population, pushing up the aged dependency rate (the population above age 64 divided by the population age 15 to 64$)$. Declines in mortality have effects across the whole age distribution, but increased life expectancy - particularly for those above age 65 - ultimately implies further growth in the aged dependency rate. According to the latest United Nations' projections, the rate is expected to double within the currently industrialized regions of the world by 2050 .

In contrast, the developing countries will experience further declines in the child dependency rate over the next half century that are expected to offset the growth in aged dependency, and the overall (child plus aged) dependency rate is projected to fall between now and 2050. Even within the two regions, the diversity of expected change is large. Japan illustrates the situation of countries with fertility rates below the long-run replacement rate in which there will be nearly two aged persons for every three working adults. The United States, on the other hand, is projected to have an aged dependency rate in 2050 that is only about half that of Japan. Equally large differences are evident between China, with an abrupt and forced decline in its birth rate, and India. China may see a growth in the proportion of its population that is aged exceeding that of the United States, while India should benefit from a continuing decline in the overall dependency rate.

And because the economic effects differ at various stages of the process, demographic change has widely varying economic and social consequences. The industrial countries are most concerned with what they perceive as the economic burden of providing for a rapidly-aging, non-productive elderly population. They anticipate both a decline in national saving and reduced investment requirements within a future pattern of slower growth in the labor force and output. The developing world is at an earlier stage in the demographic transition associated with substantial potential near-term benefits. The population of working age is still growing rapidly, and reductions in the youth dependency rate provide the opportunity to raise rates of saving and capital accumulation. Lower rates of mortality among the young and middle-aged also imply increased returns from investments in education and other forms of human capital. 
These differences in the demographic situations of the rich industrial societies and the developing world will have important implications for the future development of economic interactions between the two regions. Some analysts believe that the consumption needs of a large retired population will drive down saving in the rich industrial economies and create a global capital shortage at a time of surging investment needs in the developing world (OECD, 1996 and MGI, 1994 and 2004). Others foresee an opposing scenario in which a slowly growing or even declining population of working age leads to large declines in required investment within the industrial economies, creating a glut of saving and economic stagnation (Cutler et. al., 1990). If rates of saving decline faster than investment in the aging industrial societies, they will become more dependent on the rest of the world, leading to resource transfers from poor countries to support the consumption of the rich. Thus, while there is general agreement that the aging of the population in industrial countries will slow the overall pace of economic growth and lower rates of saving and investment, the quantitative magnitudes of the declines in saving and investment as well as the relative timing of each decline remain matters of sharp debate.

The macroeconomic consequences of population aging have been explored in a series of conceptual studies. Cutler and others (1990) examined the issue of population aging in a closed-economy model in which the reduced investment associated with lower labor force growth determines the profitability of saving. They concluded that the future economic costs of a rising aged-dependency rate could not be offset by increases in current saving because it would lead to a perpetual fall in the rate of return to capital. In fact, they argued that the optimal social response to population aging that takes the form of lower rates of labor force growth is to reduce saving and increase current consumption.

This somewhat paradoxical result follows from two assumptions. First, increased longevity is assumed to offer no utility beyond the opportunity to consume over a longer period of time: there is no tradeoff between consumption and leisure. ${ }^{6}$ If the increased longevity is primarily absorbed as increased time in retirement, there is no increase in income; more years of consumption must simply be offset by a lower average rate of

\footnotetext{
${ }^{6}$ If there is a tradeoff between consumption and utility, individuals would respond to the increased consumption needs of a longer life in part by delaying retirement. The larger labor force would also help support a higher rate of capital accumulation.
} 
consumption. Second, they assume that society has already optimized its saving in equilibrating current and future benefits of consumption. Thus, any effort to raise current rates of saving and investment in anticipation of increased retirement costs drives down the rate of return to capital, negating any gains. Furthermore, if we assume that the consumption of the young is as good as the consumption of the old, there is also no social benefit of transfers from the young to the old.

More relevant to our interests, Attanasio and Violante (2000) examine the implications of demographic change in an open global economy with full capital mobility. Specifically, they model the change within the context of two regions that are designed to be representative of the aging high-income countries and a young developing region like Latin America; and they do not assume that the world is in equilibrium. They conclude that the disparities in demographic trends create substantial opportunities for joint gains because the ability to move capital to the developing region slows the decline in its return within the developed region. Similarly, Bryant (2006) argues that crossborder capital flows can be important in mitigating some of the economic consequences of asymmetric demographic changes in industrial and developing economies.

The empirical aspects of the linkage between demographic change and the balance of national rates of saving and investment have also been explored in several studies. ${ }^{7}$ We have based our analysis on the methodology employed by Higgins (1998), which has many antecedents in the literature. The basic postulate is that rates of saving and investment are explained by a set of country-specific economic factors that change over time (X), factors that are largely time-invariant but vary across countries (C), and the age structure of the population $(\mathrm{P})$ :

$$
\begin{aligned}
& S_{i t}=F_{1}\left(X_{i t}, C_{i}, P_{i t}\right)+u_{i t} \\
& I_{i t}=F_{2}\left(X_{i t}, C_{i}, P_{i t}\right)+v_{i t}
\end{aligned}
$$

For saving, the cross-national research has identified two primary economic determinants: the level and rate of growth of income per capita. ${ }^{8}$ We also include life

\footnotetext{
7 The most recent studies that use international data are those of Higgins and Williamson (1997), Higgins (1998), Bloom and Williamson (1998), Bloom et. al. (1999), Schultz (2004), Bosworth and Keys (2004), and IMF (2005).

${ }^{8}$ The earlier studies experimented with a range of other determinants, such as interest rates and the termsof-trade, without any consistent positive results. In addition, several studies have included the lagged
} 
expectancy as a proxy for the length of the planned retirement period. ${ }^{9}$ The age structure of the population is represented by the proportions in each 5-year age bracket. Given the high degree of collinearity among the demographic terms, Higgins imposed a plausible constraint of smoothness on the age-saving profile by assuming that the coefficients were distributed along a $3^{\text {rd }}$ order polynomial, a technique first employed by Fair and Dominguez (1991). We have done the same, but because of a concern that the method may imply overly extreme weights for the very young and very old, we limited the younger group to everyone under age 15, and the older group to everyone over age 70. We also estimated the relationship using two simple categorical variables that represented the ratio of those under age 15 to those aged 15-64, and the ratio of those age 65 and over to those aged 15-64 (aged dependency rate).

For investment, the neoclassical model emphasizes a long-term expansion of the capital stock paralleling the growth of output. Output growth is, in turn, a function of the growth in the labor force and labor-augmenting technological change. Therefore, the slowing of labor force growth accompanying the aging of the population would be expected to slow the rate of investment. The age profile of the population is included as a predictor of future labor force participation, but it also yields a regression structure that parallels that of saving, making it easy to focus on the impact of demographic change on net external flows.

Our data set incorporates information on 85 countries, extending over the period 1960 to 2004. We converted all of the data to five-year averages. Thus we have a maximum of 9 observations per country. The saving and investment data are not available prior to the 1970s for many developing countries and we included a lagged measure of income change, eliminating the 1960 to 1964 period from the regression. As a result, we have a maximum of 562 observations on saving and 622 for investment. In addition, for a smaller set of industrial (22) and emerging market (18) economies we were able to divide the aggregate saving into the saving of general government (excluding public enterprises) and the private sector. We also obtained measures of the

saving or investment rate as an exogenous variable. We agree with Schultz (2004) that this is an implausible assumption that raises severe statistical problems.

${ }^{9}$ The income level and life-expectancy variables are dropped from our time dimension regressions because they are deemed too collinear with the time-invariant country effects. 
general government balance (net lending) for 80 countries (498 observations). ${ }^{10}$ Rates of saving and investment are reported as percentage of Gross National Income (GNI). Growth rates are also in percentages, but the demographic measures are recorded as proportions. Additional details on the data sources and the grouping of the countries are provided in Appendix A.

\section{Empirical Results}

Because the data set has a significant time dimension (eight observations), we can control for the influence of some country-specific socio-economic factors by using fixedeffects estimation. That is, the intercept is allowed to vary for every country, but they have common slope coefficients. The age profile is thereby assumed to be the same across all countries. We explore the potential for variation in the slope coefficients in a limited way by estimating separate regressions for groups of countries based on the phase of economic development or region. We also estimate a version with fixed time effects in which differences in the Xs and the age distribution are assumed to account for the cross-national differences in rates of saving and investment.

Time dimension. The time series estimates for national saving and investment rates of all 85 countries are reported in column (1) of Table 3. We show the categorical variable version initially because the age coefficients have a direct interpretation. Income growth, current and lagged, is highly significant and there is a very strong correlation of the demographic age structure with both saving and investment. ${ }^{11}$ Reductions in youth and aged-dependency both raise the rate of saving and investment, but changes in the aged-dependency rate have much larger effects.

The significance of the demographic effects varies across regions, however. Both demographic variables are not statistically significant at the 0.05 level for the industrial countries, and the effect of the aged dependency rate is empirically small. In contrast, the terms are large and highly significant for the Asian economies. Much of the literature on

\footnotetext{
${ }^{10}$ The government data apply to general government for OECD countries, but, for many developing economies, the measure is a central government concept.

${ }^{11}$ While the inclusion of current income growth among the set of regressors does raise some concern about estimation biases, its exclusion has no discernable effect on the age coefficients.
} 
Asian saving has stressed the role of the decline in the youth dependency rate, but in this sample the aged dependency rate has the stronger correlation. The results for Latin America are intermediate between the industrial and Asian economies. The correlations are even weaker for the residual group consisting mostly of African countries. However, if the analysis is done for all countries except Asia (column 6), the coefficients on the age variables are highly significant and close to those reported for the full sample. Thus the evidence of significant demographic effects extends beyond Asia.

The variability of the demographic effects is equally evident in the versions that represented the age-saving profile with a $3^{\text {rd }}$-order polynomial. The regressions are reported in Appendix Table B1, and they are very similar in terms of overall statistical fit to those reported in table 3 - in fact, there is little to suggest preferring one specification over the other. ${ }^{12}$ The graphical representations of the estimated age profiles are presented in Figure 5. As shown in panel A, the global average of all 85 countries yields a highly significant hump-shaped age profile for both saving and investment. It is also noteworthy that the peak of the investment profile occurs well before that of saving, an expected result if the initial entrance into the workforce induces an increased demand for capital. The highest saving rates are associated with the population aged 40-50. As reported for the categorical regressions, however, the age profiles for the industrial countries indicate very modest effects of demographic change on both saving and investment (panel B) the age profiles are very flat. In fact, the age profile for investment is inverted, implying rising investment rates are associated with the very old and the very young. Again, the strongest evidence of demographic effects comes from the results for the Asian countries (panel C). ${ }^{13}$

\footnotetext{
${ }^{12}$ The one exception is that we compute an F-statistic for the set of age coefficients used to estimate the polynomial and they are statistically significant for all the regions.

${ }^{13}$ We had some concern that the results for the industrial countries might reflect a lack of variation in either the demographic change or rates of saving and investment relative to other countries. The within-region variations are smaller than for the total sample, but the industrial countries have an above average variation in the aged-dependency rate and below average for the child-dependency rate. The variation in the saving rate is only slightly below the average. The differences between the industrial and Asian emerging markets do not seem to be related to a lack of variation.
} 
Cross-national dimension. The cross-national variation in the data is far greater than in the time series. In particular the variation in the age structure of the population across nations is larger than the change that we observe over the 45-year period for any of the regions. However, it is very likely that the cross-national variations in rates of saving and investment reflect differences in determinants other than demographics or identified economic factors. If these unidentified factors are correlated with the demographic variables, the estimates of the age effects will be biased. In addition, a focus on the cross-national variation reduces the ability to explore the regional differences. Still, estimates based on controlling for the time effects may be a useful check on the robustness of the prior results.

Table 4 displays the results from the fixed-effects estimation that suppresses the time dimension and focuses on the cross-national differences. Again, we emphasize the categorical formulation because of the ease of interpretation, but the results with the polynomial formulation are reported in the Appendix. We added the level and square of per capita income to avoid an unwarranted attribution of the higher saving rates of the wealthier countries to demographics. In addition, we found a consistent positive association between increased life expectancy and higher saving. Most surprising, the estimated age profiles from the cross-national estimation are virtually identical to those reported for the times-series. The similarity of the age effects is evident in a comparison of Tables 3 and 4 and, for the total of all 85 countries and the subgroup of Asian countries, the plots of the age profile obtained from the polynomial version (Table B2) are indistinguishable from those shown in Figure 5. The difference between the two estimates is somewhat larger for the industrial countries and Latin America.

Current account implications. Our presentation of separate statistical relationships for saving and investment assumes a degree of external openness that may not exist for many countries in our sample - particularly for the period extending back into the 1960s and 1970s. Feldstein and Horioka (1980) noted the extremely high correlation between national rates of saving and investment, and interpreted it as implying that saving and investment were not independent of one another. In such a closed economy situation, saving and investment would be forced to move together. 
In order to shed some light on this issue, we estimated a set of regressions using the current account as the dependent variable. The result, of course, is equivalent to computing the difference between the coefficients of the saving and investment equations, but the procedure provides a simple measure of significance. ${ }^{14}$ The age profiles for the total sample, the industrial countries and Asia are shown in Figure 6 and Table B3. All three have the expected humped distribution for the age profile and the Ftests for the age coefficients are significant at the 0.01 level or above for the total sample and the regional groupings other than Latin America.

Public sector. We also gathered information on the overall balance of government budgets and a measure of the surplus on current government transactions that is consistent with the concept of saving used in the national accounts. Much of the cost of population aging is expected to fall on the public sector. Thus it would be useful to know the extent to which the prior finding of a demographic effect on national saving can be associated with the public sector budget versus private saving behavior.

For the government budget balance, we obtained data for 80 countries from the International Financial Statistics for a total of 498 five-year periods. The regression results for the polynomial version are presented in Appendix Table B4, and the demographic profile is shown in Figure 7. Again, the age profile has a humped distribution, indicating that a concentration of the population in the prime working years is associated with strong budget surpluses, and an increase in either dependency rate is reflected in a shift toward deficits. The F-test for the age coefficients (Table B4) indicates significance at the .001 level for all the country groups. Surprisingly, the effect is most pronounced for the Asian economies.

Finally, for a smaller group of 40 industrial (22) and emerging market (18) economies, we obtained measures of government saving that make it possible to divide national saving into its public and private components. The regression results for government saving are reported in Table B5, and the age profiles for the total, industrial, and emerging market economies are shown in Figure 8. The parameters are statistically

\footnotetext{
${ }^{14}$ Differences in the number of available observations for saving and investment result in slightly different coefficients for the regressions we report.
} 
significant for the overall group of 40 countries and the industrial economies, but they are insignificant for the emerging market group. While all three profiles have the expected humped age pattern, the size of the effect is quite modest in an economic sense. On the other hand, the age effects for private saving, shown in Figure 9 and Table B6, are large and significant for the total sample and emerging markets, but, as with the original estimates of national saving, they are modest for the industrial countries.

\section{Individual Country Implications}

The age coefficients that we obtained from the regressions can be used to construct time-series indexes of the implied change in rates of saving and investment for individual countries. Such indexes, calibrated to rates of saving in 2000, are presented for Europe, Japan, and the United States in Figure 10. We constructed two alternative indexes using the age profile coefficients from the regressions for the average of the industrial countries and for the average of all 85 countries. Over the historical period of 1960-2005, the implied demographic-induced change in saving is broadly consistent with the secular decline in rates of saving and investment within Europe. Similarly, for Japan the implied change using the coefficients from the 85-country sample is very compatible with the decline in rates of saving and investment that has occurred over the past 30 years. However, the coefficient estimates from the industrial-country subsample imply too small of a drop in saving rates. In contrast, U.S. saving rates would have been expected to fall in the early years when the baby-boom generation raised the youth dependency rate and then to rise as the baby boomers moved into their peak earning

years. The actual saving rate shows the opposite pattern, remaining high until 1980 and then drifting down, except for a brief rise in the late 1990s that can be traced to a large swing in the budget balance.

The demographic changes are also consistent with much of the developments within Asia, where saving is predicted to rise in the 1980s and level out after the mid1990s. Of course, the indexes of demographic effects do not track the large decline in saving and investment after 1997 (Figure 3) that was initiated by the Asian financial crisis, and the strong post-2002 recovery. 
Looking ahead, however, the range of potential outcomes remains very wide. The age profile obtained from the industrial country sub-sample, for example, implies modest future changes in U.S. rates of saving - a decline of about 2 percent of GNI between now and 2050. On the other hand, the weights obtained from the full 85-country sample indicate the potential for a much larger drop equal to 10 percent of GNI. The range of potential outcomes, shown in Figure 10, is even greater for Japan and Europe because the magnitude of their future changes in the population age structure is projected to be more substantial than for the United States.

The results for the investment rate are more difficult to interpret because the estimated age profile from the polynomial regression for the industrial country sample was inverted. Thus, the projected investment rate actually rises slightly in future years, while the weights from the full sample imply a decline of about 5 percentage points by 2050. Because of the inverted age profile for investment in the industrial country subsample, we also show the demographic indexes obtained from the categorical regressions. For saving, the index based on the categorical regression is indistinguishable from that of the polynomial regression. The index for investment is much different, however, with a projected decline of about 3 percentage points by 2050 for the United States. However, that version has problems with the historical period because the coefficient on the youth dependency rate is positive. Thus, it implies that the fall in the youth dependency rate would have reduced investment over the past quarter century.

Figure 10 also highlights the important fact that, except for Japan, demographic changes have not yet had a major influence on national rates of saving and investment. Rather, it is a process whose implications are still largely in the future. For the United States, the demographic profile suggests that saving rates will fall still further from what is currently a very low level. The projected changes in saving rates far exceed those of the past.

The large divergence between the future rates of saving and investment implies that all three industrial country groups will be experiencing large current account deficits in future decades as they sell off assets to support consumption. For some developing regions of the world, such an outcome would be welcomed as they will be at an earlier stage of the demographic transition with a younger population and high domestic rates of 
saving. In addition, large exports to the developed regions would create a strong impetus to their own growth. However, external imbalances of the implied magnitude may not be sustainable on a long-term basis. There are political as well as economic problems with a sustained sell-off of national assets.

\section{The Asian Puzzle}

The non-industrial countries of Asia play a crucial role in this analysis. The implied effects of past demographic changes on rates of saving and investment far exceed those that we obtain for other regions. This result is also reflected in the frequency with which past studies of the relationship between demographic change and saving have focused on Asia. ${ }^{15}$ Explanations for the high rates of Asian saving have often emphasized the lack of a social safety net comparable to that in higher-income countries, and perhaps a greater role for dynastic saving and other cultural factors. In a recent paper, Schultz (2004) questioned the finding of large demographic effects on saving in Asia, and argued that some prior studies exaggerated the impact by including lagged saving in the regression analysis. However, his analysis still produced estimates between our results for the full 85-country sample and the sub-sample of non-industrial Asian countries. ${ }^{16}$ Thus, Asia is the source of much of the macroeconomic evidence in support of large demographic effects on saving.

Even if we accept the argument that non-industrial Asia is somehow different, we cannot be sure that the large sensitivity to demographic change will continue in future years as their incomes increase and they adopt many of the social institutions of the industrialized countries. Many of the higher-income Asian countries, for example, have begun to introduce public retirement and unemployment insurance programs.

One means of addressing the issue is to examine the situation of Japan in more detail. Japan is both a high-income society with an elaborate set of income support programs and a part of Asia. Figure 11 provides a simple comparison of the actual and predicted savings rates for the Asian sub-sample of Table B1. The degree to which the

\footnotetext{
${ }^{15}$ See, for example, Bloom, Canning, and Malaney. (1999), Bloom and Williamson (1998), and Higgins and Williamson (1997).

16 There are some differences in the sample of countries (particularly his inclusion of Japan) and his analysis ends with 1992 .
} 
observations are spread out along a 45-degree line highlights the extensive explanatory power of the relationship. We then added the results for Japan using the Asia coefficients. As can be seen, the pattern of change in Japan does not look at all like the rest of Asia. The regression predicts a far larger decline in saving than actually occurred. In an additional test, we estimated a regression for Japan's saving rate that included both the anticipated saving based on the age coefficients for the industrial countries and the measure based on the age coefficients from the Asian sub-sample. Only the industrial country version has a positive correlation.

As a second test, we re-estimated the saving and investment relationships for the Asian subsample using weighted regressions. GDP, population, and the square root of population were employed as alternative weights. In effect, these alternative equations place a greater emphasis on the saving and demographic trends of the larger economies, such as China and India. All three of these weighting schemes substantially reduced the magnitude of the demographic effect for both the total 85-country sample and Asia, but it remains statistically significant for Asia.

\section{Conclusion}

Overall, the empirical analysis yields considerable evidence of significant demographic effects on rates of saving, investment, and the current account. The results are surprisingly similar in our panel data set when viewed from either the time or crossnational perspective. The influence of demographics is also evident in measures of both public and private saving. However, the analysis is also invariant in implying that the quantitative magnitude of the effects are small for the industrial countries, particularly in contrast with the strong demographic influences that we found for the Asian economies. Contrary to the expectations expressed by Bernanke (2005), we do not find evidence that demographic change is currently exerting a significant positive effect on saving in the industrial countries. Instead, population aging has proceeded already to the point where it is and will continue to be a negative influence on saving. Finally, we would emphasize that, while we do find evidence that the age structure of the population is an important long-run determinant of national saving, it changes very slowly, and in the short run its effects are easily overwhelmed by other factors. 


\section{References}

Attanasio, Orazio P., and G.L. Violante. 2000. “The Demographic Transition in Closed and Open Economy: A Tale of Two Regions,” Working Paper 412, InterAmerican Development Bank, February 12.

Bernanke, Ben S. 2005. “The Global Saving Glut and the U.S. Current Account Deficit.” Speech given at Sanridge Lecture, Virginia Association of Economics. Richmond, VA, 10 March 2005.

Bloom, David E., David Canning, and P. N. Malaney. 1999. "Demographic Change and Economic Growth in Asia,” CID Working Paper No. 15, Harvard University.

Bloom, D. E., and J.G. Williamson. 1998. “Demography Transitions and Economic Miracles in Emerging Asia.” World Bank Economic Review 12, pp. 419-455.

Bosworth, Barry, and Benjamin Keys.2004. "Increased Life Expectancy: A Global Perspective,” in Henry J. Aaron and William B. Swartz (eds), Coping With Methuselah: The Impact of Molecular Biology on Medicine and Society (Washington D.C: The Brookings Institution Press): 247-83.

Brooks. 2002. Population Aging and Global Capital Flows in a Parallel Universe, IMF Working Paper 00/151.

Bryant, Ralph C. 2006. “Asymmetric Demographic Transitions and North-South Capital Flows.” Brookings Discussion Paper in International Economics No. 170. Washington, DC: Brookings Institution, February 2006.

Cutler, David M., James M. Poterba, Louise M. Sheiner, Lawerence H. Summers. 1990. “An Ageing Society: Opportunity or Challenge?,” Brookings Papers on Economic Activity, No. 1, pp. 1-73.

Fair, Ray C., and Kathryn M. Dominguez. 1991. "Effects of Changing U.S. Age Distribution on Macroeconomic Equations,” American Economic Review 81, pp.1276-1294.

Feldstein, Martin and Charles Horioka. 1980. "Domestic Saving and International Capital Flows,” Economic Journal 90, pp. 314-29.

Higgins, Matthew. 1998. "Demography, National Savings, and International Capital Flows," International Economic Review, Vol. 39, No. 2, pp. 343-69.

Higgins, M., and J.G. Williamson. 1997. “Age Structure Dynamics in Asia and Dependence of Foreign Capital,” Population and Development Review 23, pp.261-93.

International Monetary Fund. 2005. World Economic Outlook: Building Institutions, September, Washington D.C.

McKinsey Global Institute. 1994. The Global Capital Market: Supply, Demand, Pricing, and Allocation. Washington, DC. 
. 2004. The Coming Demographic Deficit: How Aging Populations Will Reduce Global Saving. Washington, DC.

Qureshi, Zia. 1995. “Do We Face a Global Capital Shortage,” Policy Research Working Paper No 1526, International Economics Division, the World Bank.

OECD. 1996. Future Global Capital Shortages: Real Threat or Pure Fiction? Paris, France.

Schultz, T. Paul. 2004. "Demographic Determinants of Saving: Estimating and Interpreting the Aggregate Association in Asia.” Discussion Paper No. 901, Yale University Economic Growth Center Discussion Paper Series.

Tobin, James. 1967. "Life-Cycle Saving and Balanced Growth,” in Ten Economic Studies in the Tradition of Irving Fisher. John Wiley, pp. 231-56. 
Table 1. Current Account, Selected Regions and Years

Percent of World GDP

\begin{tabular}{lccccc}
\hline Region & $1980-89$ & $1990-94$ & $1995-99$ & $2000-04$ & $2005 p$ \\
\hline U.S. & -0.45 & -0.22 & -0.51 & -1.37 & -1.81 \\
Japan & 0.26 & 0.40 & 0.34 & 0.35 & 0.39 \\
Europe & -0.04 & -0.13 & 0.28 & 0.17 & 0.16 \\
Emerging Asia & 0.02 & 0.01 & 0.14 & 0.38 & 0.55 \\
Emerging Latin & & & & & \\
America & -0.11 & -0.11 & -0.17 & -0.04 & 0.08 \\
Middle East & 0.08 & -0.09 & 0.01 & 0.17 & 0.44 \\
\hline
\end{tabular}

Source: Author's calculations as described in Appendix A. 
Table 2. Dependency Rates, Selected Regions and Years, 1950-2050 percentage

\begin{tabular}{|c|c|c|c|c|c|}
\hline & 1950 & 1975 & 2000 & 2025 & 2050 \\
\hline \multicolumn{6}{|l|}{ Aged Dependency } \\
\hline WORLD & 9 & 10 & 11 & 16 & 25 \\
\hline More Developed Regions & 12 & 17 & 21 & 33 & 44 \\
\hline United States of America & 13 & 16 & 19 & 28 & 33 \\
\hline Japan & 8 & 12 & 25 & 49 & 69 \\
\hline Less Developed Regions & 7 & 7 & 8 & 13 & 23 \\
\hline Asia less Japan & 7 & 7 & 9 & 20 & 26 \\
\hline China & 7 & 8 & 10 & 20 & 39 \\
\hline India & 6 & 7 & 8 & 12 & 22 \\
\hline Africa & 6 & 6 & 6 & 7 & 10 \\
\hline Latin America & 7 & 8 & 9 & 15 & 29 \\
\hline \multicolumn{6}{|l|}{ Child Dependency } \\
\hline WORLD & 57 & 64 & 48 & 37 & 32 \\
\hline More Developed Regions & 42 & 37 & 27 & 25 & 27 \\
\hline United States of America & 42 & 39 & 33 & 29 & 28 \\
\hline Japan & 59 & 36 & 21 & 21 & 26 \\
\hline Less Developed Regions & 64 & 75 & 53 & 39 & 32 \\
\hline Asia less Japan & 62 & 73 & 48 & 30 & 28 \\
\hline China & 54 & 70 & 36 & 26 & 26 \\
\hline India & 67 & 71 & 56 & 36 & 27 \\
\hline Africa & 77 & 87 & 79 & 63 & 44 \\
\hline Latin America & 71 & 76 & 51 & 35 & 28 \\
\hline \multicolumn{6}{|l|}{ Total Dependency } \\
\hline WORLD & 65 & 74 & 59 & 53 & 57 \\
\hline More Developed Regions & 54 & 54 & 48 & 57 & 71 \\
\hline United States of America & 54 & 55 & 51 & 57 & 61 \\
\hline Japan & 68 & 47 & 47 & 71 & 96 \\
\hline Less Developed Regions & 71 & 82 & 61 & 52 & 55 \\
\hline Asia less Japan & 68 & 80 & 57 & 50 & 55 \\
\hline China & 61 & 78 & 46 & 46 & 65 \\
\hline India & 73 & 77 & 64 & 48 & 50 \\
\hline Africa & 82 & 93 & 85 & 70 & 55 \\
\hline Latin America & 78 & 84 & 60 & 50 & 57 \\
\hline
\end{tabular}

Source: United Nations, World Population Prospects , 2005.

Note: Aged and child dependency rates measured as the population over age 65 and under age 15, respectively, divided by the working age population (15-64). 
Table 3. Saving and Investment Regressions by Major Region, Country Fixed Effects

\begin{tabular}{|c|c|c|c|c|c|c|}
\hline Variable & All Counties & $\begin{array}{l}\text { Industrial } \\
\text { Countries } \\
\end{array}$ & $\begin{array}{c}\text { Latin } \\
\text { America }\end{array}$ & Asia & Other & $\begin{array}{c}\text { All Countries } \\
\text { minus Asia }\end{array}$ \\
\hline \multicolumn{7}{|c|}{ Saving } \\
\hline GDP Growth & $\begin{array}{l}0.62 \\
(7.6)\end{array}$ & $\begin{array}{l}0.84 \\
(6.2)\end{array}$ & $\begin{array}{l}0.62 \\
(3.7)\end{array}$ & $\begin{array}{l}0.57 \\
(2.2)\end{array}$ & $\begin{array}{l}0.55 \\
(4.0)\end{array}$ & $\begin{array}{l}0.63 \\
(7.6)\end{array}$ \\
\hline Lagged GDP Growth & $\begin{array}{l}0.59 \\
(7.5)\end{array}$ & $\begin{array}{l}0.57 \\
(4.3)\end{array}$ & $\begin{array}{l}0.75 \\
(4.8)\end{array}$ & $\begin{array}{l}0.39 \\
(1.7)\end{array}$ & $\begin{array}{l}0.44 \\
(3.4)\end{array}$ & $\begin{array}{c}0.6 \\
(7.4)\end{array}$ \\
\hline Aged dependency & $\begin{array}{l}-0.54 \\
(4.3)\end{array}$ & $\begin{array}{l}-0.15 \\
(1.3)\end{array}$ & $\begin{array}{l}-0.85 \\
(2.1)\end{array}$ & $\begin{array}{l}-1.2 \\
(2.4)\end{array}$ & $\begin{array}{l}0.16 \\
(0.2)\end{array}$ & $\begin{array}{l}-0.64 \\
(4.7)\end{array}$ \\
\hline Youth dependency & $\begin{array}{l}-0.19 \\
(8.4)\end{array}$ & $\begin{array}{l}0.06 \\
(1.4)\end{array}$ & $\begin{array}{l}-0.17 \\
(4.2)\end{array}$ & $\begin{array}{l}-0.45 \\
(8.3)\end{array}$ & $\begin{array}{l}-0.12 \\
(2.5)\end{array}$ & $\begin{array}{l}-0.12 \\
(4.9)\end{array}$ \\
\hline Constant & $\begin{array}{c}0.33 \\
(14.4)\end{array}$ & $\begin{array}{c}0.2 \\
(5.5)\end{array}$ & $\begin{array}{l}0.31 \\
(6.5)\end{array}$ & $\begin{array}{l}0.57 \\
(8.5)\end{array}$ & $\begin{array}{c}0.2 \\
(3.6)\end{array}$ & $\begin{array}{c}0.29 \\
(11.6)\end{array}$ \\
\hline Adjusted R-Squared & 0.79 & 0.75 & 0.59 & 0.81 & 0.78 & 0.76 \\
\hline Countries & 85 & 22 & 22 & 13 & 28 & 71 \\
\hline Observations & 562 & 172 & 152 & 91 & 147 & 463 \\
\hline \multicolumn{7}{|c|}{ Investment } \\
\hline GDP Growth & $\begin{array}{l}0.52 \\
(7.5)\end{array}$ & $\begin{array}{l}0.51 \\
(3.9)\end{array}$ & $\begin{array}{r}0.38 \\
(2.8)\end{array}$ & $\begin{array}{l}0.66 \\
(2.7)\end{array}$ & $\begin{array}{l}0.62 \\
(5.9)\end{array}$ & $\begin{array}{c}0.5 \\
(7.0)\end{array}$ \\
\hline Lagged GDP Growth & $\begin{array}{l}0.54 \\
(8.3)\end{array}$ & $\begin{array}{l}0.53 \\
(4.2)\end{array}$ & $\begin{array}{c}0.1 \\
(0.7)\end{array}$ & $\begin{array}{l}1.02 \\
(5.5)\end{array}$ & $\begin{array}{l}0.66 \\
(6.6)\end{array}$ & $\begin{array}{l}0.45 \\
(6.5)\end{array}$ \\
\hline Aged dependency & $\begin{array}{l}-0.58 \\
(5.0)\end{array}$ & $\begin{array}{l}-0.14 \\
(1.2)\end{array}$ & $\begin{array}{l}-1.04 \\
(3.0)\end{array}$ & $\begin{array}{l}-1.97 \\
(4.2)\end{array}$ & $\begin{array}{l}-0.26 \\
(0.5)\end{array}$ & $\begin{array}{l}-0.59 \\
(4.6)\end{array}$ \\
\hline Youth dependency & $\begin{array}{l}-0.11 \\
(5.8)\end{array}$ & $\begin{array}{l}0.12 \\
(2.8)\end{array}$ & $\begin{array}{l}-0.11 \\
(3.4)\end{array}$ & $\begin{array}{l}-0.34 \\
(7.7)\end{array}$ & $\begin{array}{l}-0.01 \\
(0.2)\end{array}$ & $\begin{array}{l}-0.06 \\
(2.8)\end{array}$ \\
\hline Constant & $\begin{array}{c}0.32 \\
(15.9)\end{array}$ & $\begin{array}{l}0.19 \\
(5.6)\end{array}$ & $\begin{array}{l}0.36 \\
(9.3)\end{array}$ & $\begin{array}{l}0.51 \\
(8.5)\end{array}$ & $\begin{array}{l}0.18 \\
(4.2)\end{array}$ & $\begin{array}{c}0.29 \\
(13.1)\end{array}$ \\
\hline Adjusted R-Squared & 0.63 & 0.68 & 0.43 & 0.79 & 0.64 & 0.56 \\
\hline Countries & 85 & 22 & 22 & 13 & 28 & 71 \\
\hline Observations & 622 & 172 & 169 & 98 & 183 & 516 \\
\hline
\end{tabular}

Source: Authors' calculations as explained in text. T-statistics are in parentheses. 
Table 4. Saving and Investment Regressions by Major Region, Time Fixed Effects

\begin{tabular}{|c|c|c|c|c|c|c|}
\hline Variable & All Counties & $\begin{array}{l}\text { Industrial } \\
\text { Countries }\end{array}$ & $\begin{array}{c}\text { Latin } \\
\text { America }\end{array}$ & Asia & Other & $\begin{array}{c}\text { All Countries } \\
\text { minus Asia }\end{array}$ \\
\hline \multicolumn{7}{|c|}{ Saving } \\
\hline GDP Growth & $\begin{array}{l}0.68 \\
(6.1)\end{array}$ & $\begin{array}{l}0.68 \\
(2.9)\end{array}$ & $\begin{array}{l}0.33 \\
(1.4)\end{array}$ & $\begin{array}{l}1.11 \\
(3.4)\end{array}$ & $\begin{array}{l}0.32 \\
(1.8)\end{array}$ & $\begin{array}{l}0.43 \\
(3.4)\end{array}$ \\
\hline Lagged GDP Growth & $\begin{array}{l}0.71 \\
(6.7)\end{array}$ & $\begin{array}{l}0.56 \\
(2.5)\end{array}$ & $\begin{array}{l}0.27 \\
(1.1)\end{array}$ & $\begin{array}{l}0.90 \\
(3.0)\end{array}$ & $\begin{array}{l}0.31 \\
(1.8)\end{array}$ & $\begin{array}{l}0.48 \\
(4.0)\end{array}$ \\
\hline Income & $\begin{array}{l}0.049 \\
(2.6)\end{array}$ & $\begin{array}{c}-0.153 \\
(3.6)\end{array}$ & $\begin{array}{c}0.096 \\
(0.7)\end{array}$ & $\begin{array}{c}0.063 \\
(1.5)\end{array}$ & $\begin{array}{c}0.362 \\
(6.9)\end{array}$ & $\begin{array}{l}0.063 \\
(2.5)\end{array}$ \\
\hline Income Squared & $\begin{array}{l}-0.01 \\
(1.8)\end{array}$ & $\begin{array}{c}0.039 \\
(4.1)\end{array}$ & $\begin{array}{c}-0.035 \\
(0.3)\end{array}$ & $\begin{array}{c}-0.008 \\
(0.5)\end{array}$ & $\begin{array}{l}-0.17 \\
(6.4)\end{array}$ & $\begin{array}{c}-0.015 \\
(2.2)\end{array}$ \\
\hline Life Expectancy & $\begin{array}{l}0.002 \\
(4.6)\end{array}$ & $\begin{array}{c}0.013 \\
(5.3)\end{array}$ & $\begin{array}{l}0.001 \\
(0.8)\end{array}$ & $\begin{array}{c}0.001 \\
(0.6)\end{array}$ & $\begin{array}{l}0.004 \\
(5.4)\end{array}$ & $\begin{array}{l}0.002 \\
(4.6)\end{array}$ \\
\hline Aged dependency & $\begin{array}{l}-0.64 \\
(6.7)\end{array}$ & $\begin{array}{l}-0.14 \\
(1.3)\end{array}$ & $\begin{array}{l}-0.72 \\
(2.7)\end{array}$ & $\begin{array}{l}-1.68 \\
(3.0)\end{array}$ & $\begin{array}{l}-0.32 \\
(0.8)\end{array}$ & $\begin{array}{l}-0.40 \\
(3.7)\end{array}$ \\
\hline Youth dependency & $\begin{array}{l}-0.19 \\
(6.9)\end{array}$ & $\begin{array}{l}-0.40 \\
(6.4)\end{array}$ & $\begin{array}{l}-0.25 \\
(4.0)\end{array}$ & $\begin{array}{l}-0.19 \\
(3.1)\end{array}$ & $\begin{array}{l}0.19 \\
(3.3)\end{array}$ & $\begin{array}{l}-0.11 \\
(3.1)\end{array}$ \\
\hline $\begin{array}{l}\text { Adjusted R-Squared } \\
\text { Observations }\end{array}$ & $\begin{array}{l}0.92 \\
562\end{array}$ & $\begin{array}{l}0.98 \\
172\end{array}$ & $\begin{array}{l}0.87 \\
152\end{array}$ & $\begin{array}{c}0.97 \\
91\end{array}$ & $\begin{array}{l}0.89 \\
147\end{array}$ & $\begin{array}{l}0.9 \\
463\end{array}$ \\
\hline \multicolumn{7}{|c|}{ Investment } \\
\hline GDP Growth & $\begin{array}{l}0.62 \\
(7.4)\end{array}$ & $\begin{array}{l}0.58 \\
(3.2)\end{array}$ & $\begin{array}{l}0.17 \\
(0.9)\end{array}$ & $\begin{array}{l}0.63 \\
(2.1)\end{array}$ & $\begin{array}{c}0.7 \\
(5.3)\end{array}$ & $\begin{array}{l}0.53 \\
(5.9)\end{array}$ \\
\hline Lagged GDP Growth & $\begin{array}{l}0.51 \\
(6.4)\end{array}$ & $\begin{array}{l}0.71 \\
(3.9)\end{array}$ & $\begin{array}{l}-0.25 \\
(1.3)\end{array}$ & $\begin{array}{l}0.75 \\
(2.9)\end{array}$ & $\begin{array}{l}0.54 \\
(4.4)\end{array}$ & $\begin{array}{l}0.37 \\
(4.3)\end{array}$ \\
\hline Income & $\begin{array}{c}0.028 \\
(1.8)\end{array}$ & $\begin{array}{c}-0.064 \\
(1.9)\end{array}$ & $\begin{array}{c}-0.082 \\
(0.8)\end{array}$ & $\begin{array}{c}-0.045 \\
(1.1)\end{array}$ & $\begin{array}{c}0.173 \\
(4.4)\end{array}$ & $\begin{array}{c}0.042 \\
(2.2)\end{array}$ \\
\hline Income Squared & $\begin{array}{c}-0.011 \\
(2.4)\end{array}$ & $\begin{array}{c}0.01 \\
(1.3)\end{array}$ & $\begin{array}{c}0.063 \\
(0.8)\end{array}$ & $\begin{array}{c}0.008 \\
(0.5)\end{array}$ & $\begin{array}{c}-0.079 \\
(4.2)\end{array}$ & $\begin{array}{c}-0.014 \\
(2.7)\end{array}$ \\
\hline Life Expectancy & $\begin{array}{c}0.002 \\
(5.1)\end{array}$ & $\begin{array}{c}0.008 \\
(4.2)\end{array}$ & $\begin{array}{c}0.003 \\
(3.2)\end{array}$ & $\begin{array}{c}0.005 \\
(3.4)\end{array}$ & $\begin{array}{c}0.002 \\
(2.4)\end{array}$ & $\begin{array}{c}0.002 \\
(5.1)\end{array}$ \\
\hline Aged dependency & $\begin{array}{c}-0.28 \\
(3.7)\end{array}$ & $\begin{array}{l}-0.22 \\
(2.5)\end{array}$ & $\begin{array}{c}-0.78 \\
(3.7)\end{array}$ & $\begin{array}{l}-2.37 \\
(4.3)\end{array}$ & $\begin{array}{c}0.09 \\
(0.3)\end{array}$ & $\begin{array}{r}-0.18 \\
(2.2)\end{array}$ \\
\hline Youth dependency & $\begin{array}{l}-0.06 \\
(2.8)\end{array}$ & $\begin{array}{l}-0.17 \\
(3.4)\end{array}$ & $\begin{array}{c}-0.04 \\
(0.7)\end{array}$ & $\begin{array}{c}-0.29 \\
(4.8)\end{array}$ & $\begin{array}{l}0.11 \\
(2.5)\end{array}$ & $\begin{array}{c}0 \\
(0.0)\end{array}$ \\
\hline $\begin{array}{l}\text { Adjusted R-Squared } \\
\text { Observations }\end{array}$ & $\begin{array}{l}0.95 \\
622\end{array}$ & $\begin{array}{c}0.99 \\
172\end{array}$ & $\begin{array}{c}0.94 \\
169\end{array}$ & $\begin{array}{c}0.97 \\
98\end{array}$ & $\begin{array}{l}0.95 \\
183\end{array}$ & $\begin{array}{c}0.95 \\
516\end{array}$ \\
\hline
\end{tabular}

Source: Authors' calculations as explained in text.

Note. Income per capita is reported in 10,000s of International dollars. 
Figure 1. Saving and Investment, United States, 1960-2005



Source: Author's calculations as described in Appendix A.

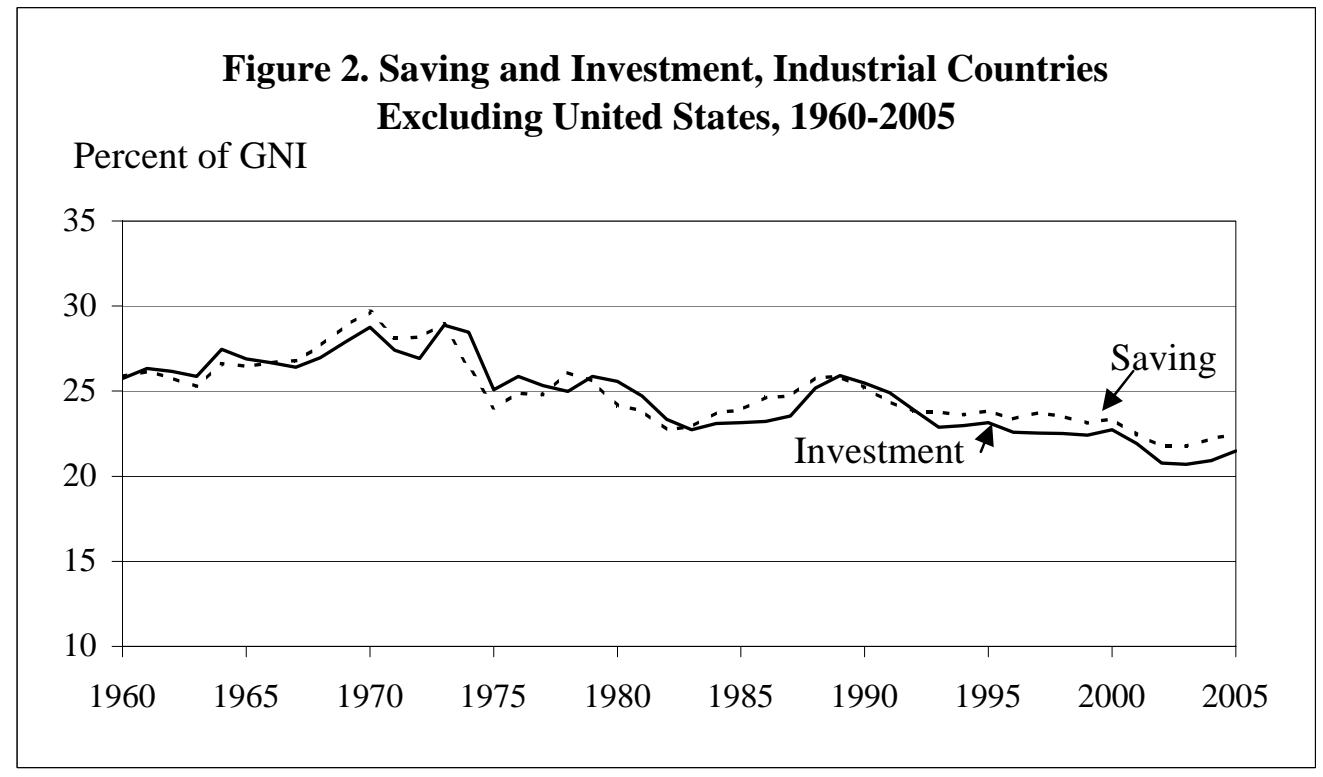

Source: Author's calculations as described in Appendix A. 


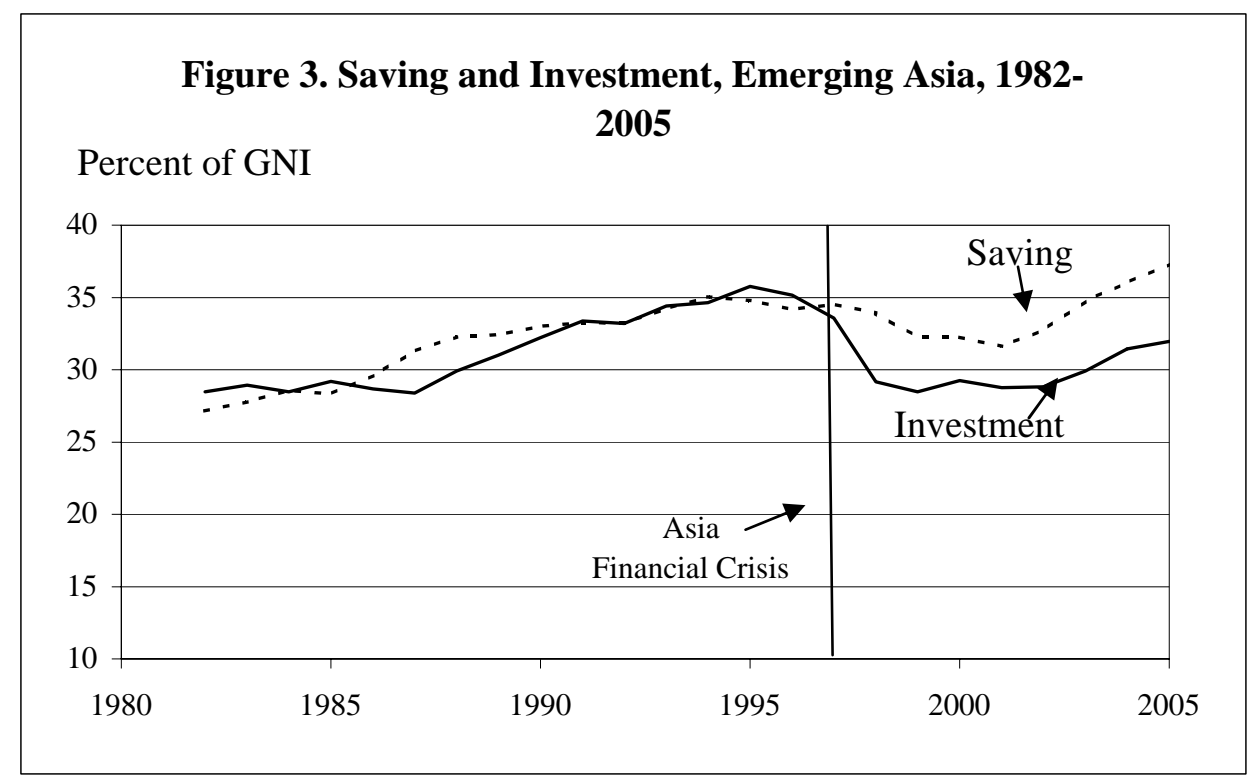

Source: Author's calculations as described in Appendix A.

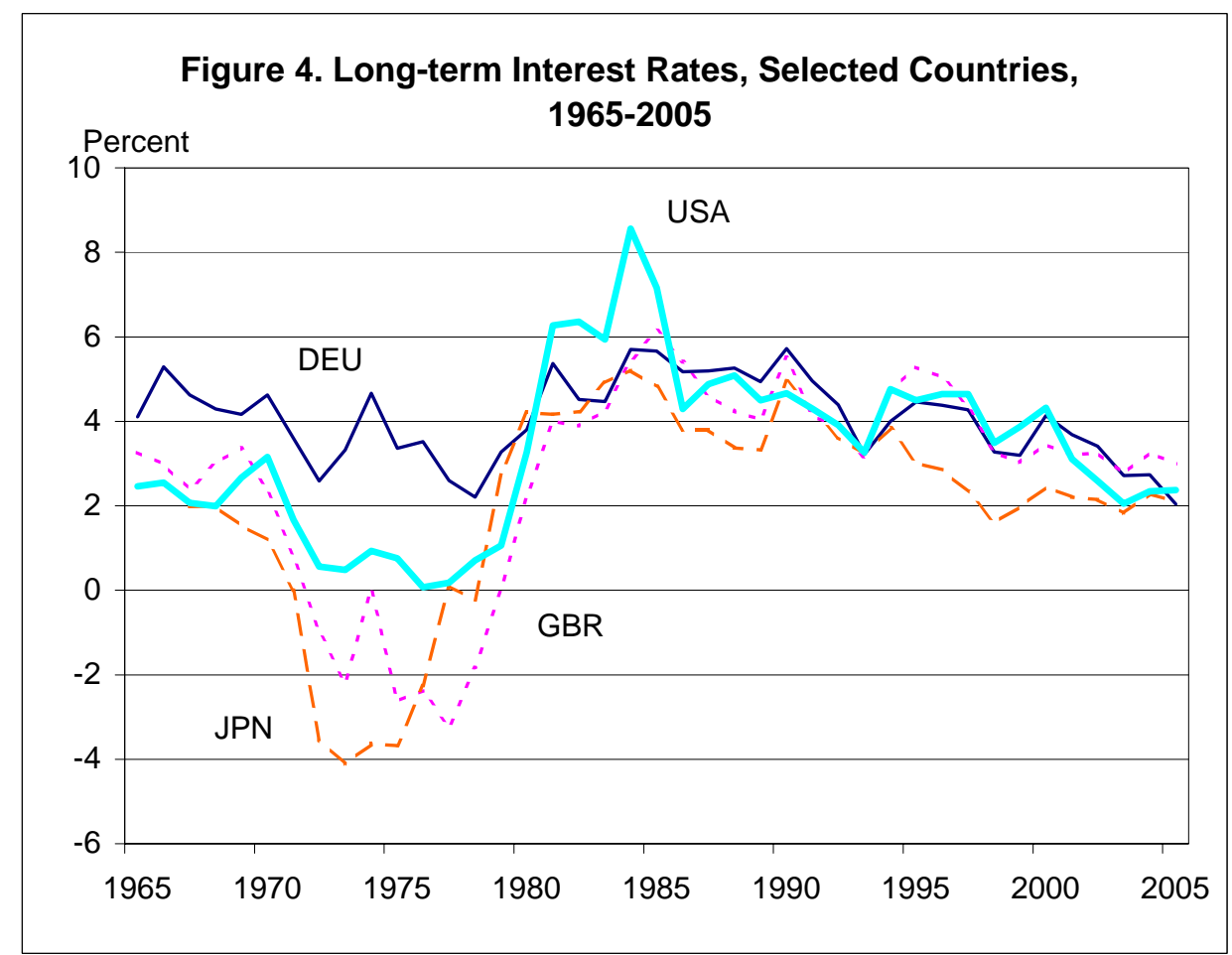

Source: OECD Economic Outlook data files. The real interest rate is computed using a five-year centered average of annual change in the consumption price deflator. 
Figure 5. Savings and Investment Profile, Country Fixed Effects, Selected Regions

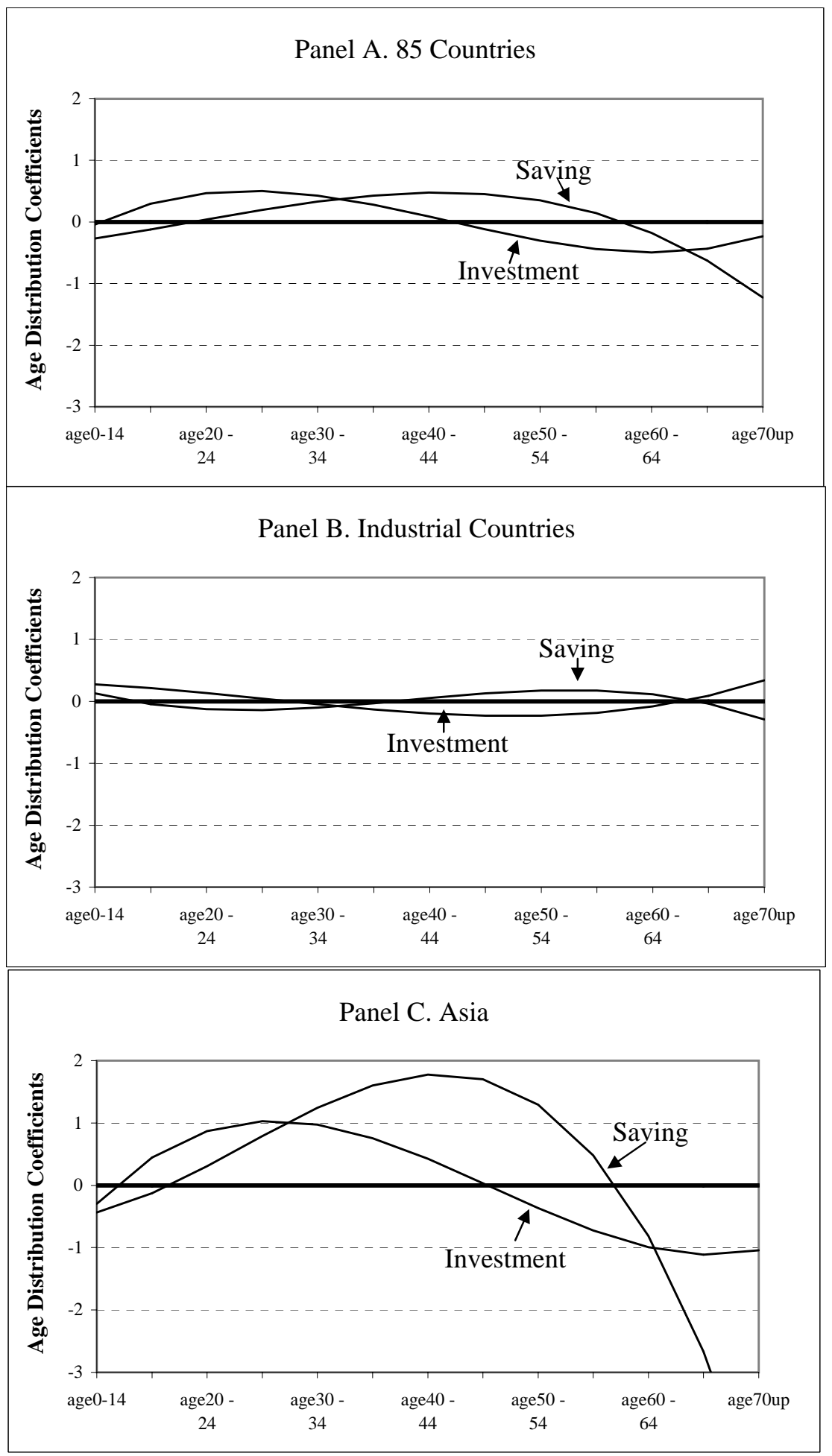

Source: Table B1 and authors' calculations as described in text. Coefficients computed based on regressions of saving (investment) as a share of GNI on real GDP growth, lagged GDP growth, and a third-order polynomial approximation of the age distribution. All variables are converted to non-overlapping five-year averages. 


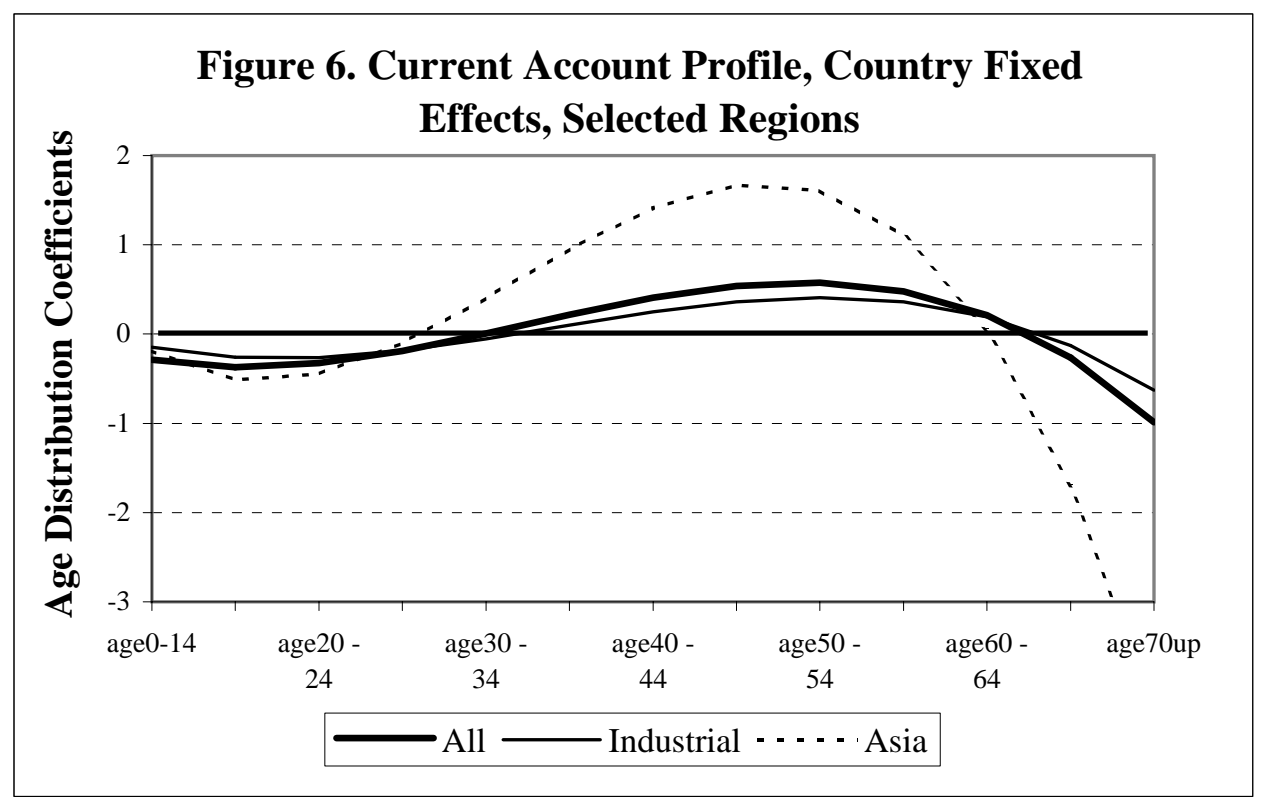

Source: Table B2 and authors' calculations as described in text. 

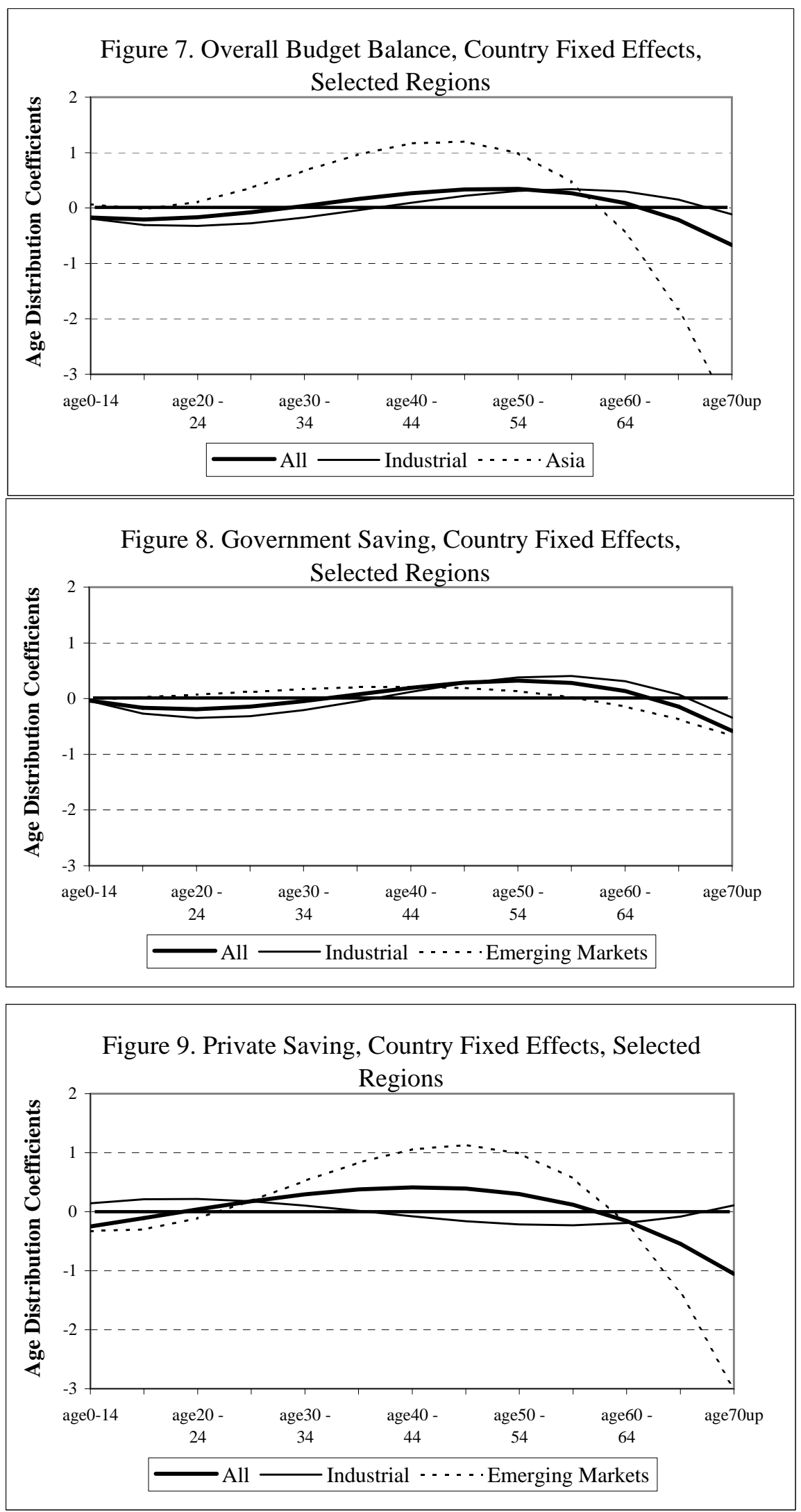

Source: Table B3-B5 and authors' calculations as described in text. 
Figure 10. Effects of Changes in the Age Structure on Saving and Investment in Selected Industrial Countries, $1960-2050$
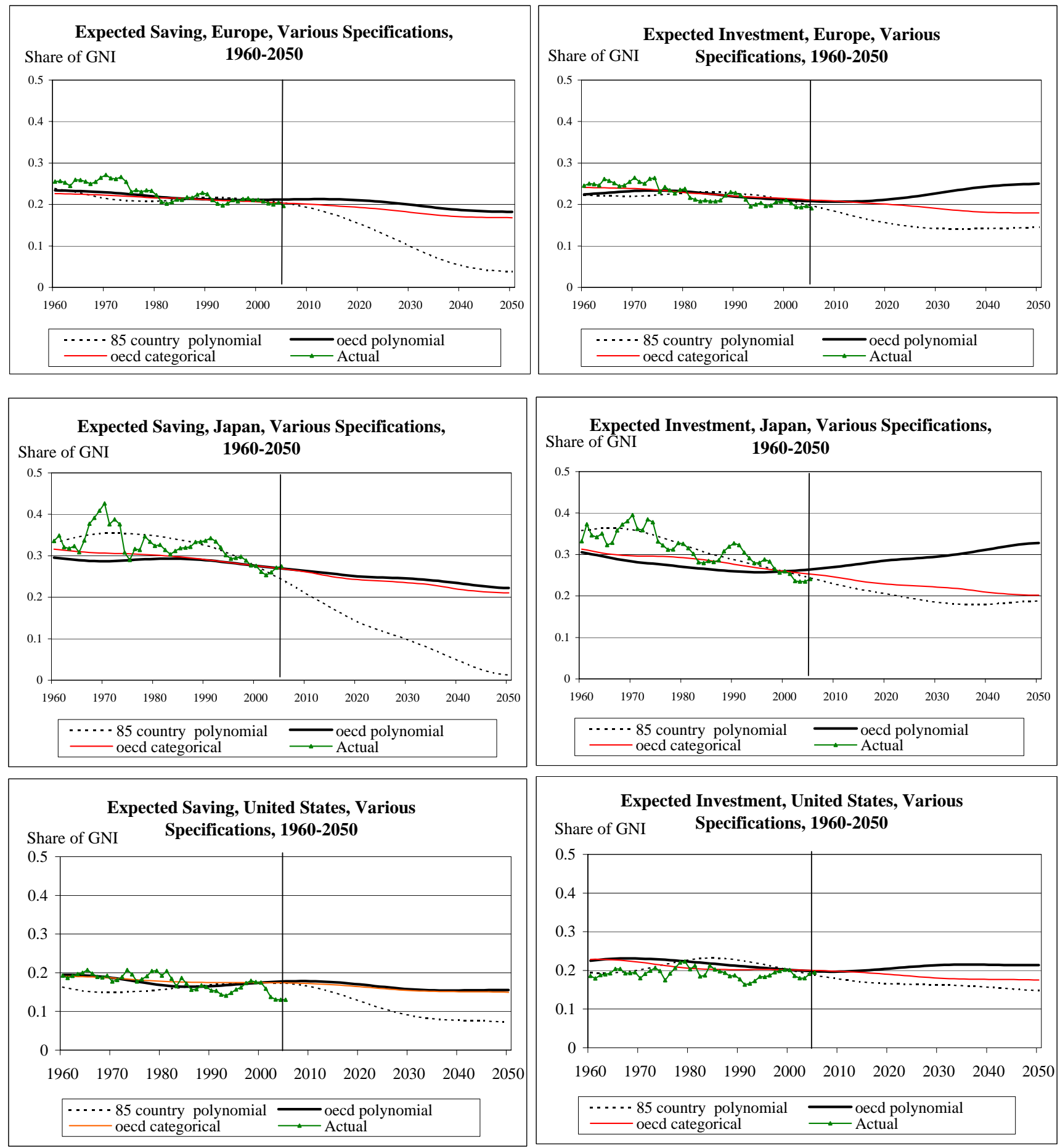

source; Authors's calculations as explained in the text. 
Figure 11. Actual and Predicted Saving Rates, Asia and Japan, Asia Coefficients percent of GNI

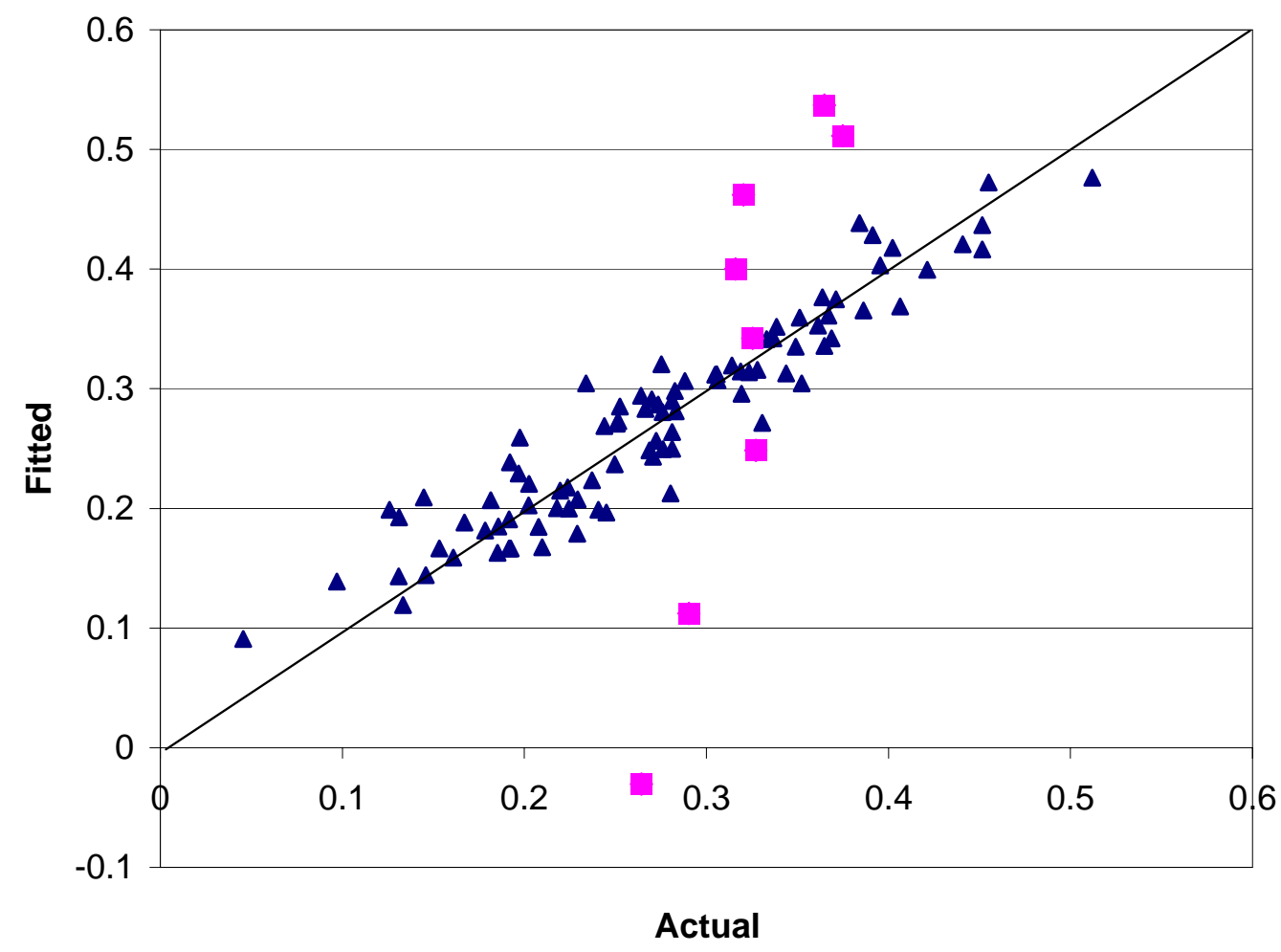

$\Delta$ Non Industrial Asia $\square$ Japan

Source: Predicted saving rates are generated from the fixed country-effects estimates for Asia (table B1). 


\section{Appendix A: Country Groupings, Data Sources and Definitions}

\section{Groupings:}

Industrial Countries (22)- Australia, Austria, Belgium, Canada, Denmark, Finland, France, Germany, Great Britain, Greece, Ireland, Iceland, Italy, Japan, Netherlands, Norway, New Zealand, Portugal, Spain, Sweden, Switzerland, United States.

Europe (16)- Austria, Belgium, Denmark, Finland, France, Germany, Great Britain, Greece, Ireland, Italy, Netherlands, Norway, Portugal, Spain, Sweden, Switzerland. Asia (13)- Bangladesh, China*, Hong Kong*, India*, Indonesia*, Malaysia*, Pakistan, Philippines*, Singapore*, South Korea*, Sri Lanka, Taiwan*, Thailand*. Latin America (22)-Argentina*, Bolivia, Brazil*, Costa Rica, Chile*, Columbia*, Dominican Republic, Ecuador*, El Salvador, Guatemala, Guyana, Honduras, Haiti, Jamaica, Mexico*, Nicaragua, Panama, Paraguay, Peru*, Trinidad and Tobago, Uruguay, Venezuela*.

Middle East (13)- Bahrain, Egypt**, Iran**, Jordan**, Kuwait, Lebanon, Libya, Oman, Qatar, Saudi Arabia, Syria, UAR, Yemen.

Other (25)- Algeria, Cote d'Ivoire, Cameroon, Cyprus, Etiopía, Ghana, Israel, Kenya, Madagascar, Mali, Mozambique, Mauritius, Malawi, Morocco, Nigeria, Rwanda, Senegal, Sierra Leone, Tanzania, Tunisia, Turkey, Uganda, South Africa, Zambia, Zimbabwe.

*Country is included in emerging market grouping.

**Country is included in "Other" category in regressions.

\section{Sources:}

Asian Development Bank (ADB).

Government Financial Statistics (GFS).

International Financial Statistics (IFS).

Organization for Economic Cooperation and Development, Statistical Compendium

(OECD).

World Bank, World Saving Database (WSD).

World Development Indicators (WDI).

World Economic Outlook Database (WEO).

Various Country Statistical Offices.

\section{Variables:}

National Saving, Investment and Current Account - OECD (industrial countries), WDI and national statistical offices.

Government Saving - OECD (industrial countries), ADB, GFS, WSD and national statistical offices.

Government Budget Balance - OECD (industrial countries) and IFS.

\section{Aggregates:}

Aggregates for industrial countries, Europe and Emerging Asia and Latin America are constructed using current period GNI (or GDP) weights, obtained by converting country GNI into U.S. dollars at market exchange rates. Aggregates for the Middle East and the World are taken from the WEO. 
Table B1. Saving and Investment Regressions, Country Fixed Effects, Selected Regions

\begin{tabular}{|c|c|c|c|c|c|c|}
\hline & \multicolumn{3}{|c|}{ Saving } & \multicolumn{3}{|c|}{ Investment } \\
\hline Variable & $\begin{array}{c}\text { Eighty-five } \\
\text { Countries }\end{array}$ & $\begin{array}{l}\text { Industrial } \\
\text { Countries } \\
\end{array}$ & Asia & $\begin{array}{c}\text { Eighty-five } \\
\text { Countries }\end{array}$ & $\begin{array}{l}\text { Industrial } \\
\text { Countries }\end{array}$ & Asia \\
\hline GDP Growth & $\begin{array}{l}0.60 \\
(7.4)\end{array}$ & $\begin{array}{l}0.85 \\
(6.3)\end{array}$ & $\begin{array}{l}0.63 \\
(2.8)\end{array}$ & $\begin{array}{l}0.53 \\
(7.6)\end{array}$ & $\begin{array}{l}0.57 \\
(4.5)\end{array}$ & $\begin{array}{l}0.58 \\
(2.3)\end{array}$ \\
\hline Lagged GDP Growth & $\begin{array}{l}0.57 \\
(7.2)\end{array}$ & $\begin{array}{l}0.57 \\
(4.2)\end{array}$ & $\begin{array}{l}0.43 \\
(2.1)\end{array}$ & $\begin{array}{l}0.54 \\
(8.3)\end{array}$ & $\begin{array}{l}0.60 \\
(4.8)\end{array}$ & $\begin{array}{l}0.93 \\
(4.8)\end{array}$ \\
\hline D1 & $\begin{array}{l}0.10 \\
(0.8)\end{array}$ & $\begin{array}{l}-0.34 \\
(2.9)\end{array}$ & $\begin{array}{l}-0.02 \\
(0.1)\end{array}$ & $\begin{array}{l}0.65 \\
(6.0)\end{array}$ & $\begin{array}{l}-0.01 \\
(0.1)\end{array}$ & $\begin{array}{l}1.31 \\
(4.7)\end{array}$ \\
\hline D2 & $\begin{array}{l}0.02 \\
(0.8)\end{array}$ & $\begin{array}{l}0.06 \\
(2.7)\end{array}$ & $\begin{array}{l}0.14 \\
(2.5)\end{array}$ & $\begin{array}{l}-0.12 \\
(5.1)\end{array}$ & $\begin{array}{l}-0.02 \\
(0.9)\end{array}$ & $\begin{array}{l}-0.21 \\
(3.3)\end{array}$ \\
\hline D3 & $\begin{array}{c}-0.003 \\
(1.9)\end{array}$ & $\begin{array}{c}-0.003 \\
(2.6)\end{array}$ & $\begin{array}{l}-0.01 \\
(3.8)\end{array}$ & $\begin{array}{l}0.005 \\
(4.3)\end{array}$ & $\begin{array}{c}0.002 \\
(1.4)\end{array}$ & $\begin{array}{l}0.01 \\
(2.2)\end{array}$ \\
\hline Constant & $\begin{array}{c}0.20 \\
(10.8)\end{array}$ & $\begin{array}{c}0.18 \\
(13.8)\end{array}$ & $\begin{array}{l}0.06 \\
(0.9)\end{array}$ & $\begin{array}{l}0.11 \\
(6.4)\end{array}$ & $\begin{array}{c}0.14 \\
(11.6)\end{array}$ & $\begin{array}{l}0.03 \\
(0.4)\end{array}$ \\
\hline Adjusted R-Squared & 0.79 & 0.76 & 0.87 & 0.64 & 0.70 & 0.78 \\
\hline F-statistic (D1=D2=D3=0) & 25.57 & 3.86 & 48.54 & 18.14 & 9.97 & 17.18 \\
\hline Prob $>$ F & 0.0000 & 0.0107 & 0.0000 & 0.0000 & 0.0000 & 0.0000 \\
\hline Countries & 85 & 22 & 13 & 85 & 22 & 13 \\
\hline Observations & 562 & 172 & 91 & 622 & 172 & 98 \\
\hline
\end{tabular}

Source: Authors' calculations as explained in text. 
Table B2. Saving and Investment Regressions, Time Fixed Effects, Selected Regions

\begin{tabular}{|c|c|c|c|c|c|c|}
\hline \multirow[b]{2}{*}{ Variable } & \multicolumn{3}{|c|}{ Saving } & \multicolumn{3}{|c|}{ Investment } \\
\hline & $\begin{array}{l}\text { Eighty-five } \\
\text { Countries }\end{array}$ & $\begin{array}{l}\text { Industrial } \\
\text { Countries }\end{array}$ & Asia & $\begin{array}{l}\text { Eighty-five } \\
\text { Countries }\end{array}$ & $\begin{array}{l}\text { Industrial } \\
\text { Countries }\end{array}$ & Asia \\
\hline GDP Growth & $\begin{array}{l}0.69 \\
(6.1)\end{array}$ & $\begin{array}{l}0.86 \\
(3.7)\end{array}$ & $\begin{array}{l}1.00 \\
(3.5)\end{array}$ & $\begin{array}{l}0.62 \\
(7.4)\end{array}$ & $\begin{array}{l}0.62 \\
(3.3)\end{array}$ & $\begin{array}{l}0.64 \\
(2.1)\end{array}$ \\
\hline Lagged GDP Growth & $\begin{array}{l}0.71 \\
(6.6)\end{array}$ & $\begin{array}{l}0.65 \\
(2.9)\end{array}$ & $\begin{array}{l}0.88 \\
(3.3)\end{array}$ & $\begin{array}{l}0.51 \\
(6.4)\end{array}$ & $\begin{array}{l}0.72 \\
(3.9)\end{array}$ & $\begin{array}{l}0.78 \\
(3.0)\end{array}$ \\
\hline GDP per Capita & $\begin{array}{l}0.05 \\
(2.5)\end{array}$ & $\begin{array}{l}-0.11 \\
(2.5)\end{array}$ & $\begin{array}{l}0.02 \\
(0.6)\end{array}$ & $\begin{array}{l}0.03 \\
(1.8)\end{array}$ & $\begin{array}{l}-0.05 \\
(1.6)\end{array}$ & $\begin{array}{c}-0.08 \\
(1.8)\end{array}$ \\
\hline GDP per Capita Squared & $\begin{array}{l}-0.01 \\
(2.1)\end{array}$ & $\begin{array}{l}0.03 \\
(3.0)\end{array}$ & $\begin{array}{l}0.00 \\
(0.0)\end{array}$ & $\begin{array}{l}-0.01 \\
(2.1)\end{array}$ & $\begin{array}{l}0.03 \\
(3.0)\end{array}$ & $\begin{array}{l}0.00 \\
(0.0)\end{array}$ \\
\hline Life Expectancy & $\begin{array}{l}0.003 \\
(5.2)\end{array}$ & $\begin{array}{l}0.012 \\
(4.9)\end{array}$ & $\begin{array}{l}0.00 \\
(2.2)\end{array}$ & $\begin{array}{c}0.003 \\
(5.2)\end{array}$ & $\begin{array}{l}0.012 \\
(4.9)\end{array}$ & $\begin{array}{l}0.00 \\
(2.2)\end{array}$ \\
\hline D1 & $\begin{array}{l}0.03 \\
(0.1)\end{array}$ & $\begin{array}{l}-0.02 \\
(0.1)\end{array}$ & $\begin{array}{l}-0.83 \\
(2.1)\end{array}$ & $\begin{array}{l}0.40 \\
(2.6)\end{array}$ & $\begin{array}{l}0.12 \\
(0.6)\end{array}$ & $\begin{array}{l}0.60 \\
(1.4)\end{array}$ \\
\hline D2 & $\begin{array}{l}0.04 \\
(0.9)\end{array}$ & $\begin{array}{l}0.04 \\
(1.0)\end{array}$ & $\begin{array}{l}0.27 \\
(3.2)\end{array}$ & $\begin{array}{l}-0.07 \\
(2.2)\end{array}$ & $\begin{array}{l}0.00 \\
(0.0)\end{array}$ & $\begin{array}{l}-0.03 \\
(0.3)\end{array}$ \\
\hline D3 & $\begin{array}{c}-0.003 \\
(1.6)\end{array}$ & $\begin{array}{c}-0.003 \\
(1.5)\end{array}$ & $\begin{array}{l}-0.02 \\
(3.9)\end{array}$ & $\begin{array}{c}0.003 \\
(1.9)\end{array}$ & $\begin{array}{c}-0.001 \\
(0.3)\end{array}$ & $\begin{array}{l}0.00 \\
(0.5)\end{array}$ \\
\hline Constant & $\begin{array}{c}0.002 \\
(0.0)\end{array}$ & $\begin{array}{l}-0.43 \\
(2.7)\end{array}$ & $\begin{array}{l}-0.36 \\
(3.4)\end{array}$ & $\begin{array}{c}0.033 \\
(1.1)\end{array}$ & $\begin{array}{l}-0.26 \\
(2.0)\end{array}$ & $\begin{array}{l}-0.43 \\
(3.5)\end{array}$ \\
\hline Adjusted R-Squared & 0.53 & 0.48 & 0.76 & 0.39 & 0.51 & 0.63 \\
\hline F-statistic (D1=D2=D3=0) & 21.24 & 16.32 & 12.21 & 5.17 & 4.03 & 8.79 \\
\hline Prob $>$ F & 0.0000 & 0.0107 & 0.0000 & 0.0016 & 0.0085 & 0.0000 \\
\hline Observations & 562 & 172 & 91 & 622 & 172 & 98 \\
\hline
\end{tabular}

Source: Authors' calculations as explained in text. 
Table B3. Current Account Regressions, Country Fixed Effects, Selected Regions

\begin{tabular}{lccc}
\hline Variable & $\begin{array}{c}\text { Eighty-five } \\
\text { Countries }\end{array}$ & $\begin{array}{c}\text { Industrial } \\
\text { Countries }\end{array}$ & Asia \\
\hline GDP Growth & 0.02 & 0.28 & -0.08 \\
& $(0.3)$ & $(1.9)$ & $(0.3)$ \\
Lagged GDP Growth & 0.13 & -0.04 & -0.43 \\
& $(1.8)$ & $(0.2)$ & $(1.8)$ \\
D1 & -0.35 & -0.33 & -1.14 \\
& $(2.9)$ & $(2.7)$ & $(3.7)$ \\
D2 & 0.10 & 0.08 & 0.32 \\
& $(4.2)$ & $(3.3)$ & $(4.7)$ \\
D3 & -0.006 & -0.005 & -0.02 \\
& $(4.8)$ & $(3.6)$ & $(4.9)$ \\
Constant & 0.09 & 0.04 & 0.01 \\
& $(4.8)$ & $(2.8)$ & $(0.2)$ \\
Adjusted R-Squared & 0.61 & 0.46 & 0.57 \\
F-statistic (D1=D2=D3=0) & 26.12 & 6.38 & 19.44 \\
Prob > F & 0.0000 & 0.0004 & 0.0000 \\
Countries & 85 & 22 & 13 \\
Observations & 562 & 172 & 90 \\
\hline Source: Authors' calculations as explained in text. &
\end{tabular}

Source: Authors' calculations as explained in text. 
Table B4. Government Overall Balance Regressions, Country Fixed Effects, Selected Regions

\begin{tabular}{lccc}
\hline Variable & $\begin{array}{c}\text { All } \\
\text { Countries }\end{array}$ & $\begin{array}{c}\text { Industrial } \\
\text { Countries }\end{array}$ & Asia \\
\hline GDP Growth & 0.47 & 0.60 & 0.15 \\
& $(7.1)$ & $(6.6)$ & $(1.0)$ \\
Lagged GDP Growth & 0.14 & 0.42 & 0.05 \\
& $(2.2)$ & $(4.7)$ & $(0.4)$ \\
D1 & -0.18 & -0.26 & -0.52 \\
& $(1.8)$ & $(3.0)$ & $(3.2)$ \\
D2 & 0.06 & 0.07 & 0.18 \\
& $(2.8)$ & $(3.9)$ & $(4.4)$ \\
D3 & -0.004 & -0.004 & -0.01 \\
& $(3.3)$ & $(4.2)$ & $(4.9)$ \\
Constant & 0.01 & 0.01 & -0.24 \\
& $(0.6)$ & $(0.6)$ & $(4.3)$ \\
Adjusted R-Squared & 0.00 & 0.00 & 0.00 \\
F-statistic (D1=D2=D3=0) & 11.92 & 17.52 & 13.38 \\
Prob > F & 0.0000 & 0.0000 & 0.0000 \\
Countries & 80 & 38 & 13 \\
Observations & 498 & 268 & 83 \\
\hline Source: Authors' calculations as explained in text. &
\end{tabular}

Source: Authors' calculations as explained in text. 
Table B5. Government Saving Regressions, Country Fixed Effects, Selected Regions

\begin{tabular}{lccc}
\hline Variable & $\begin{array}{c}40 \\
\text { Countries }\end{array}$ & $\begin{array}{c}\text { Industrial } \\
\text { Countries }\end{array}$ & $\begin{array}{c}\text { Emerging } \\
\text { Markets }\end{array}$ \\
\hline \multirow{2}{*}{ GDP Growth } & 0.42 & 0.72 & 0.26 \\
& $(4.4)$ & $(4.7)$ & $(2.2)$ \\
Lagged GDP Growth & 0.32 & 0.57 & 0.20 \\
& $(3.3)$ & $(3.8)$ & $(1.7)$ \\
D1 & -0.33 & -0.50 & 0.01 \\
& $(3.3)$ & $(4.1)$ & $(0.0)$ \\
D2 & 0.08 & 0.10 & 0.01 \\
& $(3.9)$ & $(4.3)$ & $(0.4)$ \\
D3 & -0.004 & -0.005 & -0.001 \\
& $(4.1)$ & $(4.1)$ & $(0.6)$ \\
Constant & 0.03 & 0.02 & -0.03 \\
& $(2.7)$ & $(1.6)$ & $(0.7)$ \\
Adjusted R-Squared & 0.60 & 0.67 & 0.52 \\
F-statistic (D1=D2=D3=0) & 7.20 & 8.11 & 1.03 \\
Prob > F & 0.0001 & 0.0001 & 0.3826 \\
Countries & 40 & 22 & 18 \\
Observations & 279 & 155 & 124 \\
\hline Source: Authors' calculations as explained in text. &
\end{tabular}


Table B6. Private Saving Regressions, Country Fixed Effects, Selected Regions

\begin{tabular}{lccc}
\hline Variable & $\begin{array}{c}40 \\
\text { Countries }\end{array}$ & $\begin{array}{c}\text { Industrial } \\
\text { Countries }\end{array}$ & $\begin{array}{c}\text { Emerging } \\
\text { Markets }\end{array}$ \\
\hline GDP Growth & 0.15 & 0.31 & 0.25 \\
& $(1.2)$ & $(2.0)$ & $(1.3)$ \\
Lagged GDP Growth & 0.15 & -0.06 & 0.43 \\
& $(1.1)$ & $(0.4)$ & $(2.3)$ \\
D1 & 0.11 & 0.19 & -0.34 \\
& $(0.8)$ & $(1.5)$ & $(1.3)$ \\
D2 & 0.02 & -0.05 & 0.15 \\
& $(0.6)$ & $(1.9)$ & $(2.4)$ \\
D3 & -0.002 & 0.002 & -0.011 \\
& $(1.5)$ & $(1.9)$ & $(2.9)$ \\
Constant & 0.24 & 0.16 & 0.19 \\
& $(18.1)$ & $(11.8)$ & $(2.9)$ \\
Adjusted R-Squared & 0.70 & 0.71 & 0.76 \\
F-statistic (D1=D2=D3=0) & 14.30 & 5.16 & 18.69 \\
Prob > F & 0.0000 & 0.0021 & 0.0000 \\
Countries & 40 & 22 & 18 \\
Observations & 273 & 155 & 118 \\
\hline Source: Authors' calculations as explained in text &
\end{tabular}

Source: Authors' calculations as explained in text. 


\section{RECENT WORKING PAPERS FROM THE \\ CENTER FOR RETIREMENT RESEARCH AT BOSTON COLLEGE}

The Repeal of the Retirement Earnings Test and the Labor Supply of Older Men Gary V. Engelhardt and Anil Kumar, February 2007

Persistence in Labor Supply and the Response to the Social Security Earnings Test Leora Friedberg and Anthony Webb, December 2006

Annuitized Wealth and Consumption at Older Ages

Barbara A. Butrica and Gordon B.T. Mermin, December 2006

Risk and Reward of International Investing for U.S. Retirement Savers: Historical Evidence

Gary Burtless, December 2006

State Age Protection Laws and the Age Discrimination in Employment Act Joanna Lahey, November 2006

Age, Women, and Hiring: An Experimental Study

Joanna Lahey, November 2006

Optimal Retirement Asset Decumulation Strategies: The Impact of Housing Wealth Anthony Webb, Robert Triest, and Wei Sun, November 2006

The Impact of Aggregate Mortality Rise on Defined Benefit Pension Plans Irena Dushi, Leora Friedberg, and Anthony Webb, November 2006

Health Care Costs, Taxes, and the Retirement Decision: Conceptual Issues and Illustrative Simulations

Rudolph G. Penner and Richard W. Johnson, November 2006

Why Do Boomers Plan to Work So Long?

Gordon B.T. Mermin, Richard W. Johnson, and Dan Murphy, November 2006

Job Tenure and Pension Coverage

Alicia H. Munnell, Kelly Haverstick, and Geoffrey Sanzenbacher, October 2006

All working papers are available on the Center for Retirement Research website (http://www.bc.edu/crr) and can be requested by e-mail (crr@bc.edu) or phone (617-552-1762). 